\title{
Evaluating the potential for grey seal predation to explain elevated natural mortality in three fish species in the southern Gulf of St. Lawrence
}

\author{
Hugues P. Benoît ${ }^{1, *}$, Douglas P. Swain ${ }^{1}$, W. Don Bowen ${ }^{2}$, Greg A. Breed ${ }^{3}$, \\ Mike O. Hammill ${ }^{4}$, Valerie Harvey ${ }^{4}$ \\ ${ }^{1}$ Gulf Fisheries Centre, Fisheries and Oceans Canada, Moncton, New Brunswick E1C 9B6, Canada \\ ${ }^{2}$ Bedford Institute of Oceanography, Fisheries and Oceans Canada, Dartmouth, Nova Scotia B2Y 4A2, Canada \\ ${ }^{3}$ Department of Biology, Dalhousie University, Halifax, Nova Scotia B3H 4J1, Canada \\ ${ }^{4}$ Institut Maurice Lamontagne, Fisheries and Oceans Canada, Mont-Joli, Quebec G5H 3Z4, Canada
}

\begin{abstract}
Despite 2 decades of very low fishing levels, numerous NW Atlantic demersal fish stocks have failed to recover from collapsed states or are presently collapsing. In the southern Gulf of St. Lawrence, adult natural mortality $(M)$ appears to be the demographic rate that most limits population productivity in at least 3 species: Atlantic cod Gadus morhua, white hake Urophycis tenuis and winter skate Leucoraja ocellata. The causes of elevated $M$ are not well understood, though there is indirect evidence consistent with an effect of predation by grey seals Halichoerus grypus. However, direct evidence is lacking due to uncertainty in the seal diet. Consequently, Monte Carlo simulations were undertaken using data on the spatial overlap between the seals and the fishes and a seal food-consumption model, to estimate the plausibility that different seal-diet compositions could explain observed $M$ levels. Under the simulation assumptions, we find that predation could explain up to 20 to $50 \%$ of $M$ in adult white hake and cod even if these species comprise a small percentage of grey seal diets $(<25 \%)$. If seals consume some of these fish only partially, by selectively feeding on soft tissues, a predation effect becomes more plausible. Predation can also plausibly explain the observed elevated $M$ in adult winter skate, even if they comprise a negligible $(<0.1 \%)$ percentage of the grey seal diet. Though the simulations deal with the factors that shape the potential for predation, a greater understanding of prey selection is required to conclude whether grey seals are actually adversely impacting these fish populations.
\end{abstract}

KEY WORDS: Energetics model · Monte Carlo simulation · Generalist predator · Natural mortality · Belly-biting $\cdot$ Partial consumption

\section{INTRODUCTION}

The failure of NW Atlantic groundfish stocks to recover from population collapses that occurred in the early 1990s, despite severely curtailed fishing, has generated numerous hypotheses but few conclusions regarding its cause (DFO 2003, Shelton et al. 2006). Potential contributing causes include unreported fishery catches (e.g. Bousquet et al. 2010), fisheries-induced life-history change (e.g. Rochet
1998, Hutchings 2005, Hutchings \& Baum 2005, but see Swain 2011), impaired recruitment at low stock size (e.g. Myers et al. 1999, Frank \& Brickman 2000), adverse environmental effects (e.g. Dutil \& Lambert 2000) and food-web interactions (e.g. Swain \& Sinclair 2000, Savenkoff et al. 2007). One such interaction, predation by pinnipeds, has received considerable attention (Mohn \& Bowen 1996, Fu et al. 2001, Chouinard et al. 2005, Trzcinski et al. 2006, Chassot et al. 2009). The reason for this is likely twofold. First, 
the link is direct and easy to visualise: abundant seal species such as harp Phoca groenlandica and grey seals Halichoerus grypus eat commercially important fish species, though the degree to which this occurs is uncertain. Second, the populations of both harp and grey seals grew rapidly in the latter half of the 20th century, recently reaching the highest levels on record (Hammill 2005, DFO 2009). Harvesters increasingly encounter these species around their fishing gear and have long viewed them as direct competitors.

Establishing the role of seal predation in the dynamics of NW Atlantic fish populations has been hindered by difficulties in obtaining unbiased estimates of prey composition in the predator's diet. These diets have traditionally been inferred using hard parts (mainly otoliths) recovered from seal digestive tracts or in faeces (e.g. Murie \& Lavigne 1985, Hammill et al. 2007). There are numerous potential sources of bias inherent in this method, such as the differential digestibility of different species and sizes of prey (e.g. Bowen 2000, Grellier \& Hammond 2006). Also, the heads (and otoliths) and other hard parts of some fish, principally larger ones, may selectively not be ingested (e.g. Moore 2003, Gudmundson et al. 2006, Hauser et al. 2008), leaving little or no specific evidence of the predation event. Furthermore, diets inferred from seal stomach contents reflect feeding that occurred 5 to $8 \mathrm{~h}$ prior to sampling, while those from intestines and scats typically reflect feeding in the preceding 2 to $3 \mathrm{~d}$ (Grellier \& Hammond 2006). Because these samples are only collected in accessible areas, on or near land, diet estimates do not properly reflect offshore feeding (see e.g. Fig. 1). Likewise, weather conditions may hinder sampling during certain months, potentially leading to a seasonal bias in the inferred diet. Seal diets have been estimated also using quantitative fatty acid signature analysis, which in principle should provide a better integration of spatio-temporal variability in prey consumption (Iverson et al. 2004, Iverson 2009). However, like the more traditional methods, experimental feeding experiments and field studies have identified problems with this technique (e.g. Nordstrom et al. 2008, Grahl-Nielsen et al. 2011).

In the absence of a representative diet for seals, traditional trophic modelling approaches aimed at understanding the predator's influence on fish populations, such as mass balance models (e.g. Savenkoff et al. 2007), extended single-species assessment models (e.g. Fu et al. 2001) and minimum realistic models (e.g. Punt \& Butterworth 1995), are likely to provide misleading results. Furthermore, because the direction and magnitude of some of the biases in seal diets are poorly characterised, formulating a tractable set of reasonable alternate diet scenarios for simulation is difficult. However, inferences on sealfish interactions can still be made in the absence of reliable diet information. An alternative approach that does not include diet as an input uses the factors that constrain annual consumption of particular prey by the predator to consider the potential for a predation effect (e.g. Williams et al. 2004, Matthiopoulos et al. 2008). These constraints include the bioenergetic demand of the predator, itself a function of the abundance and sizes of individuals, spatio-temporal overlap with the prey, prey abundance and prey quality (size and energy content). Because the mean and error of many of these constraints can be quantified, it is possible to establish whether and under which conditions (i.e. seal diet composition) predation could plausibly explain an important component of mortality in fish species of interest.

We applied this constraints-based inverse modelling approach to a study of predation by grey seals on 3 marine fish species with endemic populations in the southern Gulf of St. Lawrence (sGSL; Fig. 1): Atlantic cod Gadus morhua, winter skate Leucoraja ocellata and white hake Urophycis tenuis. These fish species were selected because all 3 share the common characteristic of an adult natural (non-fishing) mortality rate $(M)$ that has risen over the past 3 decades (Fig. 2), reaching levels that render the populations at risk of extirpation given current productivity conditions (Swain \& Chouinard 2008, Swain et al. 2009a, Benoît et al. 2011). Grey seals are the focal marine mammal predator for the present study because they are the principal seal species feeding in the area (Hammill \& Stenson 2000), and because the abundance of the grey seal populations that feed to some extent in the sGSL has increased in tandem with changes in fish $M$ (our Fig. 3; Bowen et al. 2003, 2007, Hammill 2005). Furthermore, grey seals are known predators of the 3 fish species of interest, with cod and white hake jointly comprising $\sim 30 \%$ of the energy in diet samples obtained in the sGSL (Beck et al. 2007, Hammill et al. 2007). We constructed a simulation that includes a published bioenergetics model for grey seals (e.g. Mohn \& Bowen 1996, Hammill \& Stenson 2000), and fish-seal spatio-temporal overlap, quantified using satellite-telemetry results (seals) and bottom-trawl surveys (fish). We then estimated the relative likelihood that different fractions of the fishes' $M$ could be explained by seal predation given different assumptions for the composition of seal diets. 


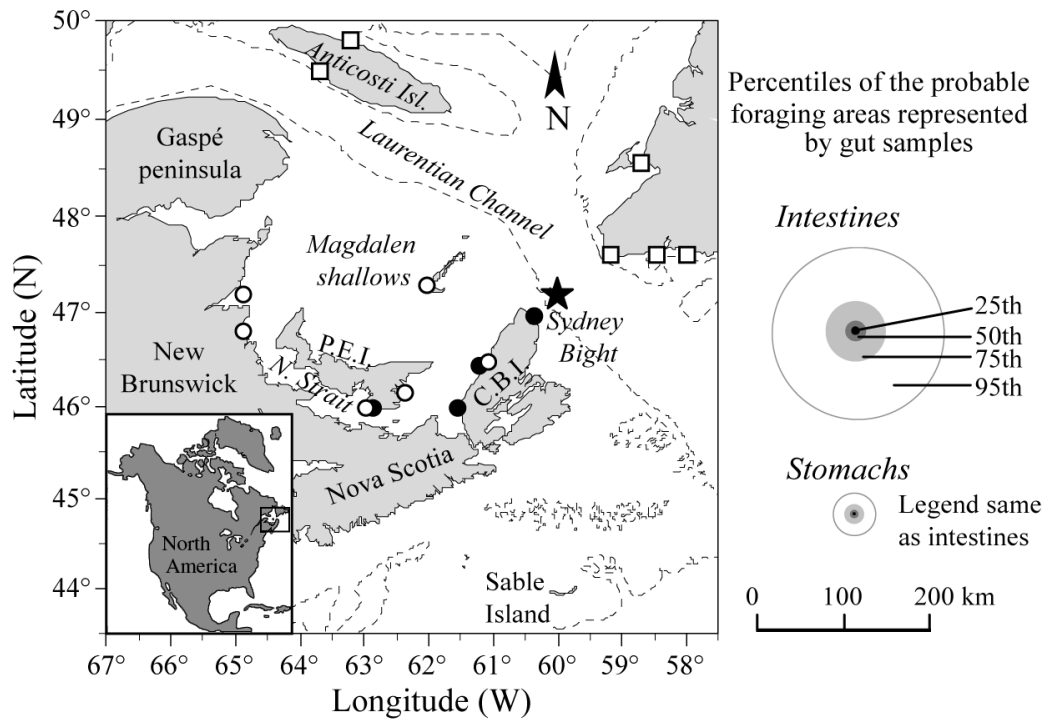

Fig. 1. Map of the southern Gulf of St. Lawrence and neighbouring eastern Scotian Shelf. The $200 \mathrm{~m}$ isobath is shown $(---)$. Also shown are the locations where grey seal stomach $(\square)$ and intestine $(\bullet$, , ) content samples have been taken either during spring and summer $(\square, 0)$ or late autumn and winter $(\bullet)$ since 1994 (Hammill et al. 2007, M. Hammill unpubl. data). The location of the sample mentioned in 'Methods' (winter 2008 diet sample) is shown ( $\star$ ). The legend to the right of the map shows the probable foraging area represented by each gut-content sample. The concentric circles reflect percentiles of net potential distance travelled by seals during the period represented by a diet sample, based on an analysis of movements from satellite-tagged seals and gut-residency times for prey (H. Benoît unpubl.). C.B.I. = Cape Breton Island $($ Nova Scotia), N. Strait = Northumberland Strait, P.E.I. = Prince Edward Island

\section{METHODS}

Our goal was not to model interannual patterns in consumption of fish by grey seals, but rather to establish whether seal predation could be an important component of recent elevated $M$ in the 3 fish species. The focal year for the study was 2005, since this is the most recent year for which there are estimates of many model input parameters (e.g. abundance, mortality). Abundance and size composition of both grey seals and fish in that year are representative of recent trends (i.e. there is no evidence that 2005 was an outlier).

The simulation model used is comprised of 3 main parts, which are described in more detail below: a consumption model for grey seals (a function of abundance, demography and estimated bioenergetic demands); parameters describing the abundance, demography and energy content of the 3 fish species; and estimates of seal-fish spatial and temporal overlap. Monte Carlo sampling from the assumed error distributions of the various parameters that describe the predation process was used to generate a set of simulation realisations that characterise the uncer- tainty in the process. The simulation is based on a monthly time step.

\section{Simulation components}

\section{Seal abundance}

NW Atlantic grey seals occur yearround in the sGSL. For management purposes, the population is divided into 3 herds or colonies that feed to some extent in the sGSL, and each is defined by their breeding area: the Gulf herd that breeds on small islands or pack ice in the sGSL, the Sable Island herd, and a Coastal Nova Scotia herd that breeds on small islands along the eastern and southwestern shores of Nova Scotia (Fig. 1). Abundance in all 3 herds has increased substantially since the mid1960s, particularly at Sable Island (our Fig. 3; Bowen et al. 2003, 2007, Hammill 2005). Based on traditional tagging and satellite telemetry of Gulf and Sable Island individuals, these herds use the sGSL to different degrees (our Fig. 4; Stobo et al. 1990, Goulet et al. 2001, Breed et al. 2006).

Grey seal abundance, $\mathrm{N}_{\text {seal }}$, in each herd in 2005 and associated estimation error were obtained from an updated fit of the deterministic age-structured model of Mohn \& Bowen (1996) (see Hammill et al. 1998, Hammill 2005, Bowen et al. 2007). For each iteration of our simulation, the beginning-of-the-year abundance of grey seals in each herd was drawn from a normal distribution (Table 1) and divided among ages ( 0 to $39 \mathrm{yr}$ ) using the average age structure from the population model. Within-year natural mortality of seals (instantaneous annual rate, $M_{\text {stage }}$ ) was incorporated as a deterministic effect: $M_{\text {Sable\&Coastal pups }}=$ $0.103, M_{\text {Gulf pups }}=0.146$, and $M_{\text {ages } 1+}=0.051$ (Trzcinski et al. 2006). The number of seals alive in month number $m$ is $\mathrm{N}_{\text {seal,age }} \times \exp \left(-M_{\text {stage }} \times m / 12\right)$.

\section{Seal energetics}

The basic model of grey seal consumption used in the simulations is identical in structure and in the value of most parameters to the model used in other recent studies (e.g. Mohn \& Bowen 1996, Hammill \& Stenson 2000, Trzcinski et al. 2006). This model is 

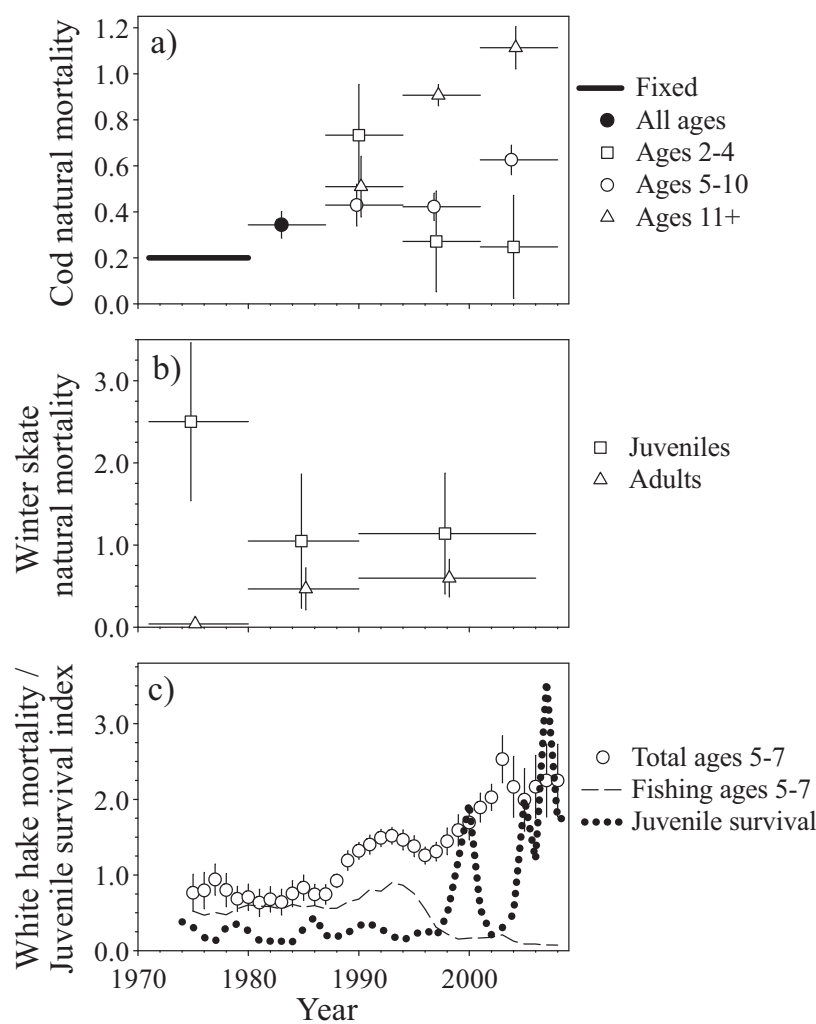

Fig. 2. Gadus morhua, Leucoraja ocellata and Urophycis tenuis. Age- or stage-dependent trends in mortality. (a) Agedependent trends in cod natural mortality (mean $\pm 2 \mathrm{SE}$; redrawn from Swain et al. 2009b). Natural mortality was estimated via sequential population analysis for blocks of years (horizontal lines), assuming a fixed rate from 1971 to 1979 and estimating a common rate across ages for 1980 to 1986 (see Swain et al. 2009b for details). (b) Stage-dependent estimates of winter skate natural mortality (mean \pm 95 percentile range) in approximately decadal blocks of years (horizontal lines) from a Bayesian state-space model (Swain et al. 2009a). (c) Index of juvenile survival (...: numbers at age 3 yr in Year $t$ divided by the spawning stock biomass in Year $t-3)$, and age 5-7 yr total mortality (O: mean $\pm 2 \mathrm{SE}$ ) and fishing mortality (- - ) for white hake estimated in the present study (Benoît \& Swain 2011)

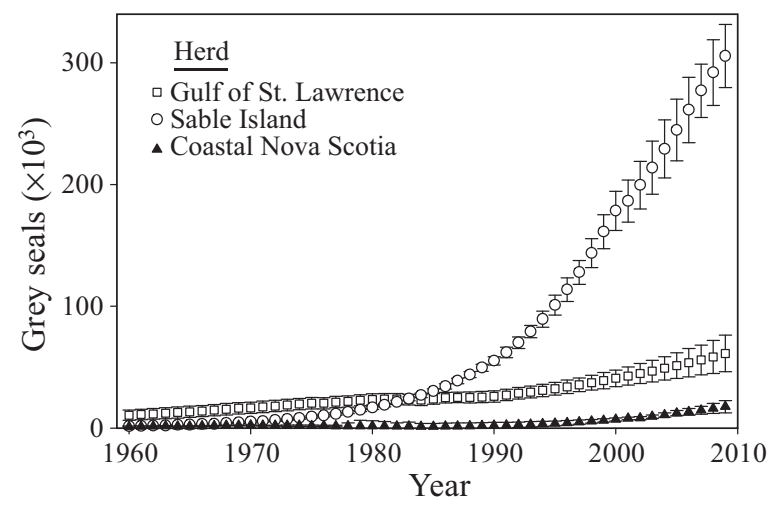

Fig. 3. Halichoerus grypus. Abundance of grey seals (mean $\pm 2 \mathrm{SE}$ ) in the $3 \mathrm{NW}$ Atlantic herds considered accurate to the extent that the various experiments and observations used to construct and parameterise it accurately reflect seal bioenergetics in the wild.

The daily gross energy intake $\left(\mathrm{GEI} ; \mathrm{kJ} \mathrm{d}^{-1}\right)$ of an individual grey seal was estimated as:

$$
\mathrm{GEI}_{s, a, m}=\alpha W_{s, a, m}^{\beta} \cdot \mathrm{AF} \cdot \mathrm{GP}_{a} \cdot \mathrm{ME}^{-1}
$$

where $s, a$ and $m$ index sex, age and month, respectively; $\alpha$ is the intercept and $\beta$ is the scaling exponent for the Kleiber equation $\alpha W_{s, a, m}^{\beta}$ (Kleiber 1975) describing the allometric relationship between seal body mass $(W)$ and metabolism; GP is a growth premium that accounts for the additional energy required by rapidly growing young seals; $\mathrm{AF}$ is the 'activity factor' that accounts for increased metabolism due to activity in the field; and ME is the metabolisable energy (i.e. assimilation efficiency or the proportion of GEI available to the seal for maintenance and growth) (Table 1).

Summer sex-specific seal mass-at-age $W_{s, a}$ (in kg) was estimated using a Gompertz growth model (Mohn \& Bowen 1996) fit to individual seal masses collected in the Gulf:

$$
W_{s, a}=\gamma_{1 s} \cdot \exp \left[-\gamma_{2 s} \cdot \exp \left(-\gamma_{3 s} \cdot a\right)\right]
$$

where $\gamma_{1}, \gamma_{2}$ and $\gamma_{3}$ are model parameters (Table 1). Variability in $W_{s, a}$ was introduced by sampling from probability distributions for each of the parameters of Eq. (2) (Table 1). The $W_{s, a}$ were adjusted for seasonal changes in mass due to growth, lactation and reduced feeding during moulting and breeding following Beck et al. (2003) to produce values of mass as a function of age in years and months, $W_{s, a, m}$ (Fig. 5). Uncertainty in basal metabolism estimates was simulated by drawing values of the Kleiber equation parameters from a multivariate normal distribution with an assumed coefficient of variation (CV) of $25 \%$ for each parameter and a negative correlation between the parameters, typical of linear regression (Table 1).

Average daily energy requirements of free-living and captive seals vary between 1.7 and 3 times the basal metabolic rate, with most studies estimating a value around 2 (Innes et al. 1987, Worthy 1987a,b, 1990, Castellini et al. 1992, Sparling \& Fedak 2004). To account for this uncertainty, values for AF were sampled from a pert distribution, a modified beta distribution that acts like a smoothed triangular distribution (e.g. Overholtz \& Link 2007), here with a range of 1.7 to 3.0 and a mode at 2.0.

The GP adjusts the GEI for the elevated metabolic rate of juveniles relative to adults (Lavigne et al. 1986, Innes et al. 1987). In the simulation, age- 
Fig. 4. Halichoerus grypus. Summary of the geographic distribution of grey seals in the southern Gulf of St. Lawrence and neighbouring areas, by herd (rows) and for 2 example seasons, winter and summer (columns). The incrementing grey shading represents increasing grey seal density based on the 10th (lightest grey), 25th, 50th, 75th and 90th (black) percentiles for non-zero density in each panel. The percentage of transmitting tagged seals that occurred in the represented geographic area in the season in question is shown in the left corner of each panel
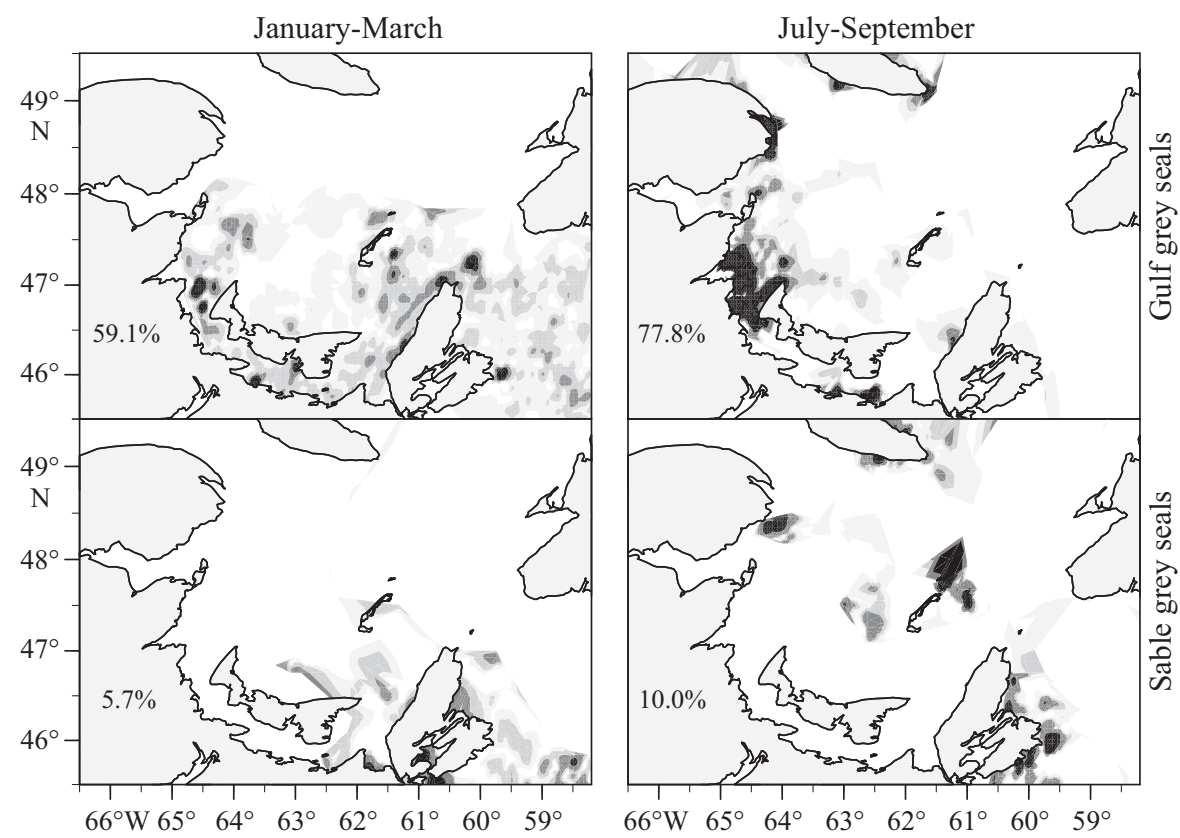

specific values of GP were drawn from uniform distributions with ranges based on results from published studies (Table 1). Simulated values for ME were based on results of experiments (Ronald et al. 1984) (Table 1). The simulations included periods of fasting as observed for wild grey seals: $21 \mathrm{~d}$ during lactation/breeding for females ages 5+ yr (occurring between late December and February), $24 \mathrm{~d}$ for adult males (ages 9+ yr) during breeding, and 2 wk during moulting (May for females, June for males).

Fish abundance, natural mortality and body size

A standardised annual bottom-trawl survey conducted each September since 1971 in the sGSL provides information on the abundance and demographic structure (size and, for some species, age) of a large number of marine fish species (Hurlbut \& Clay 1990, Benoît 2006, Benoît \& Swain 2008). These data were used to estimate the abundance and $M$ of cod, white hake and winter skate, though the manner in which this was done differed somewhat between species.

The principal assessment model for sGSL cod is a sequential population analysis (SPA). SPA reconstructs total abundance-at-age using fishery landings-at-age and assumptions concerning $M$, and is calibrated to survey catches-at-age. We define $M$ as the instantaneous rate of natural mortality whereby $\exp (-M)$ is the proportion of fish surviving the year in the absence of fishing. By fixing values of $M$ for the years prior to 1980 , Swain et al. (2009b) estimated $M$ in 7 or 8 yr blocks for the period 1980 to 2008. For the 2001-2008 period, values of $M$ were estimated for 3 cod age groups: ages 2-4, 5-10 and 11+ yr.

Trends in survival of cod to age 2 yr (not shown here) are uncorrelated with seal population growth, rather being strongly related to spawning stock biomass and an inferred impact of predation by pelagic fishes (Swain \& Sinclair 2000, Swain et al. 2000, 2009b). Likewise, trends in $M$ of cod aged 2 to $4 \mathrm{yr}$ are also inconsistent with a predominant seal effect, peaking in about 1990 and declining since then (Fig. 2a). In contrast, trends in $M$ for ages 5-10 and $11+\mathrm{yr}$ cod have generally been increasing, particularly for the latter age group. As a result, cod ages $5 \mathrm{yr}$ and older were included in the simulations. Because estimates of cod abundance-at-age $\left(\mathrm{N}_{\text {cod,a }}\right)$ and $M$ from the SPA are correlated within age groups, a multivariate normal distribution was used to generate values during the simulations (Table 1).

Estimates of relative abundance of sGSL white hake from the survey were converted to absolute abundances using a length-dependent relationship for survey efficiency (i.e. catchability) derived for demersal roundfishes (Harley \& Myers 2001). These abundance values were assumed to follow a normal distribution (Table 1). Benoit \& Swain (2011) estimated trends in the total mortality $Z$ ( $Z=M+$ fishing mortality) of white hake ages 5 to 7 yr using a modified catch-curve analysis (Sinclair 2001). Trends in $M$ were obtained given assumptions for catchability and observed fishery catches (Benoit et al. 2011), indicating that $M$ has 


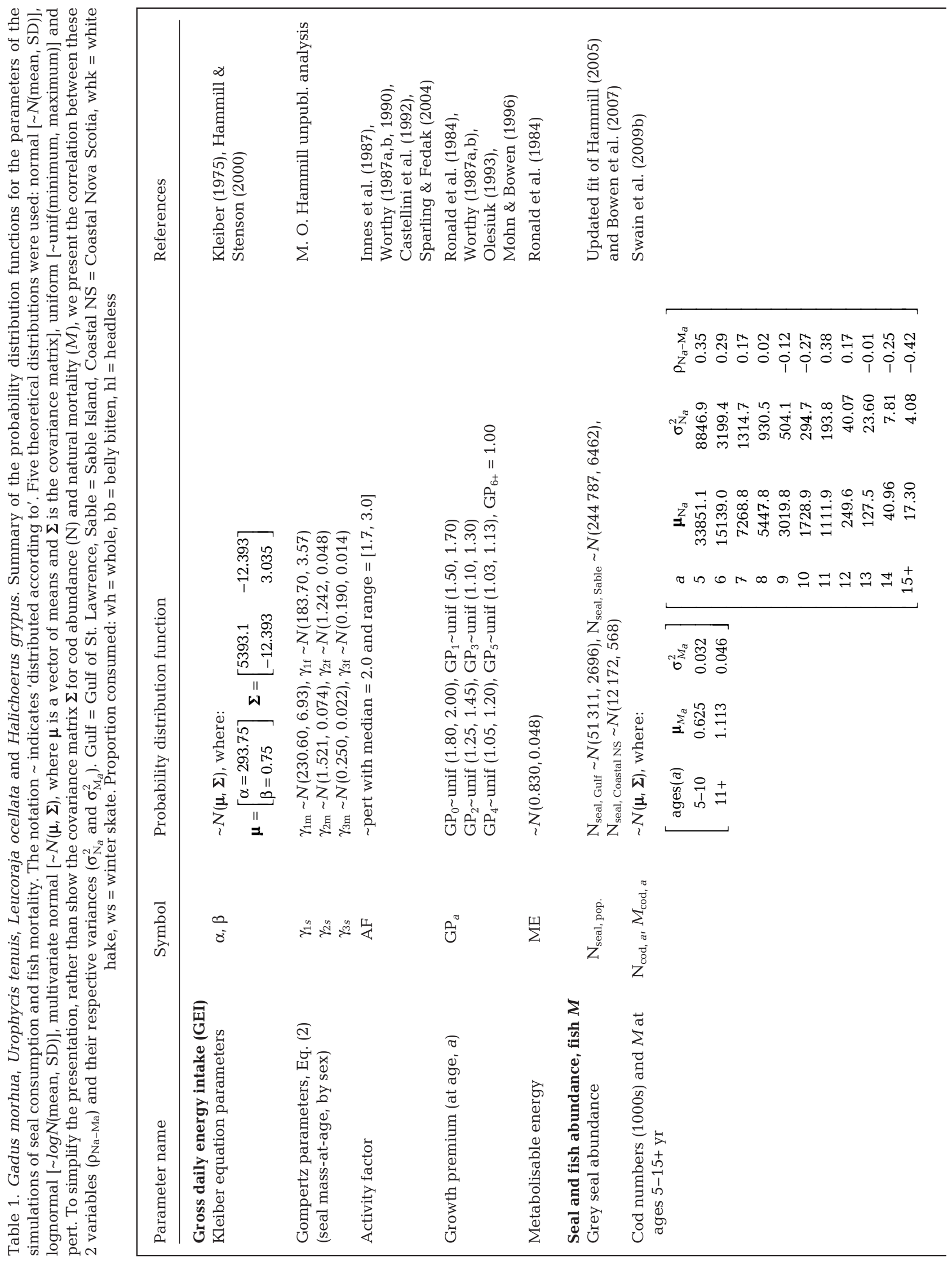




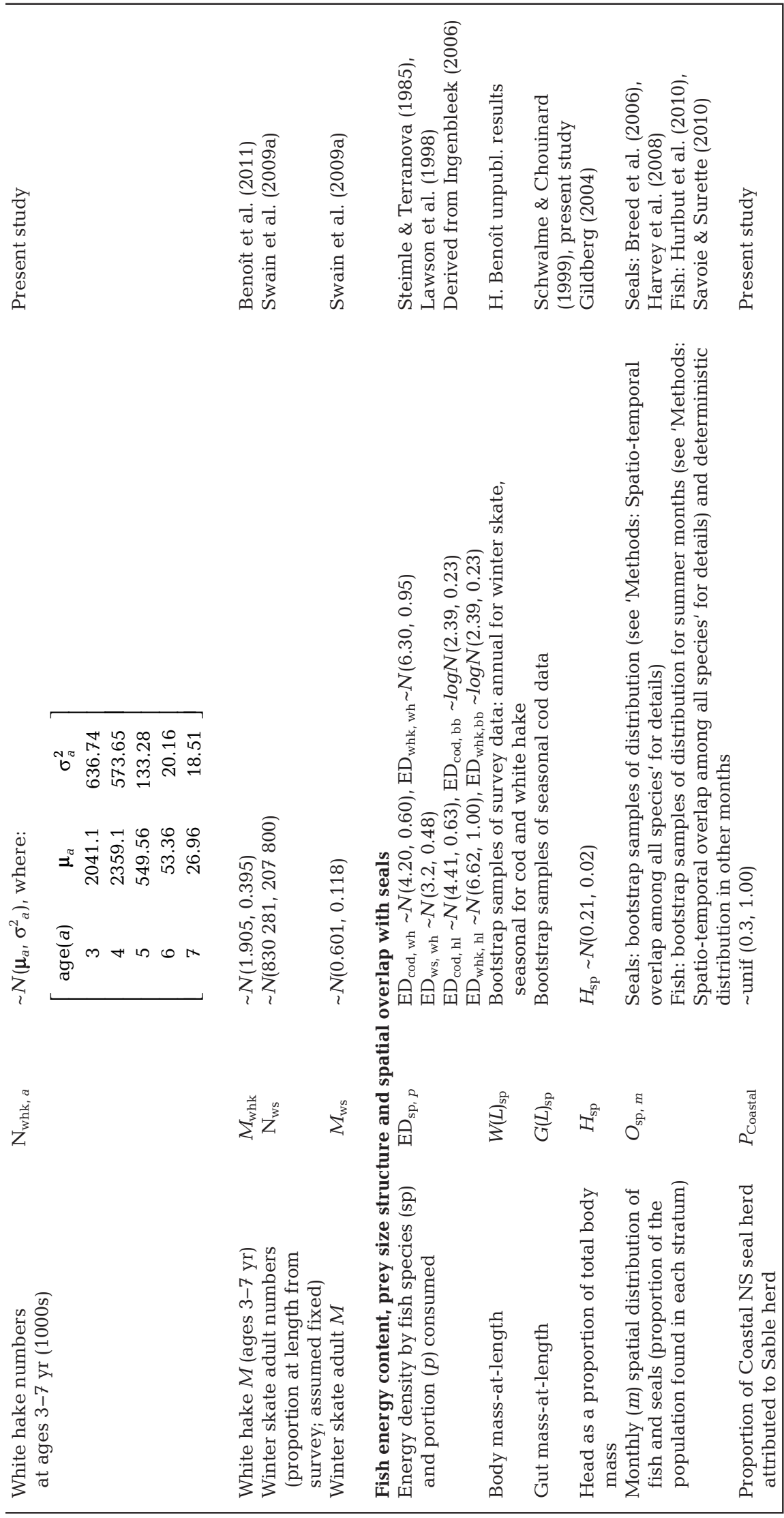

risen to a very high level of around 1.9 in recent years (Fig. 2c). For the simulations, the values of $M$ estimated for 2005 were assumed to apply to white hake ages 3 to $7 \mathrm{yr}$ (Table 1). In contrast, survival of juveniles (up to age $3 \mathrm{yr}$ ) appears to have increased (Fig. 2c), consistent with the reduction in predation mortality caused by the reduction in the abundance of large-sized piscivorous fish (Benoît \& Swain 2008). This reduction appears to exceed the potential effects of predation by expanding grey seal populations. Consumption of juvenile white hake was therefore not included in the simulations.

Swain et al. (2009a) used a Bayesian stage-structured model to estimate trends in $M$ for juvenile (individuals $<42 \mathrm{~cm}$ ) and adult southern Gulf winter skate in approximately decadal blocks. Inputs to their model included catchabilty-adjusted abundance and estimates of fishery catches. Estimated juvenile winter skate $M$ decreased dramatically from the 1970s to the period covering the 1980s to mid-2000s (Fig. 2b), a trend that is inconsistent with a strong effect of seal predation. Juveniles were therefore not included in the simulations. In contrast, adult $M$ increased over the series (Fig. 2b), consistent with a hypothesised impact of seal predation. The posterior distribution of adult winter skate $M$ estimated for the period 1990 to 2006 (Swain et al. 2009a) and the 2005 catchabilityadjusted survey abundance was used in our simulations (Table 1).

Numbers-at-age of cod and white hake were converted to numbersat-length $(\mathrm{cm})$ and vice versa in the simulations using survey-derived age-length matrices. For winter skate, the 2005 survey lengthfrequency distribution was used. The length-specific biomass of each species was calculated using survey-derived length-mass relation- 


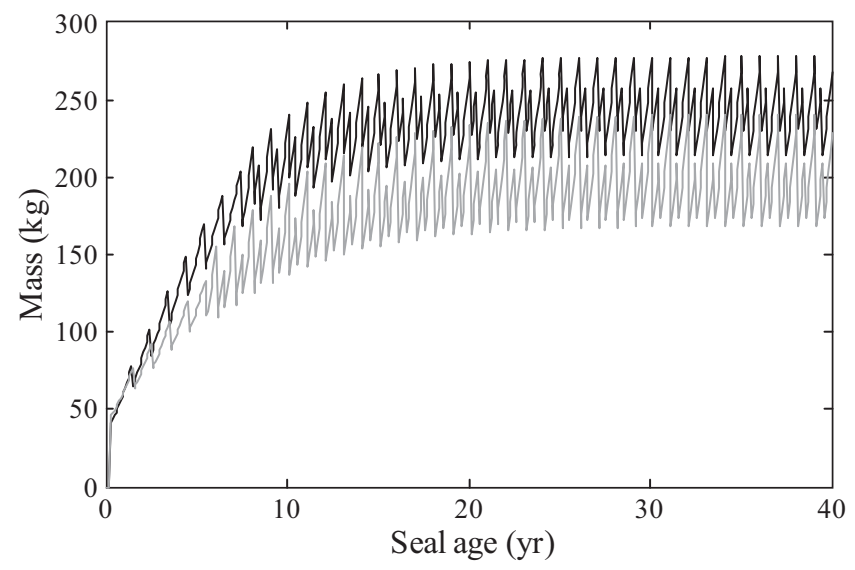

Fig. 5. Halichoerus grypus. Seasonal and interannual patterns in female (grey line) and male (black line) grey seal mass used in the simulation model

ships. Cod and white hake have a pronounced seasonal cycle in mass-at-length (Schwalme \& Chouinard 1999, H. Benoît unpubl. results). The relationships were therefore estimated by yearly quarter using data from multi-species seasonal surveys conducted from 1986 to 1991 (Clay 1991) and coddirected sampling during the 1990s and 2000s (e.g. Schwalme \& Chouinard 1999), with values adjusted to 2005 values based on observations from the September surveys. The seasonal cycle in winter skate mass-at-length is less pronounced; therefore a single length-mass relationship was used (H. Benoît unpubl. results). Variability in length-mass relationships was incorporated in the simulation using a bootstrap of observed values.

\section{Partial consumption of fish prey}

Seals do not always consume their prey whole. Belly-biting, whereby seals consume only the viscera of their prey, has been reported by fish harvesters and has been documented for harp seals feeding on free-swimming large cod in Newfoundland, Canada (Lilly \& Murphy 2004). Others have documented seals consuming all but the heads of fishes (e.g. Roffe \& Mate 1984, Moore 2003, Hauser et al. 2008). For large prey, these behaviours are consistent with optimal foraging theory, whereby seals may maximise their net rate of energy acquisition by differentially feeding on the most energy-rich or easiest-to-process portions of individual prey items, leaving a prey partially consumed when it is more profitable to search for another intact prey item (e.g. Sih 1980, Gende et al. 2001).
Although there are no data on the importance of partial consumption by seals in the wild, the fact that it is has been reported elsewhere suggested that it might be an important mode of feeding. Therefore, we simulated 2 independent selective feeding scenarios, belly-biting and head-rejection, for cod and white hake (see section 'Methods: Simulation scenarios and output metrics' below). Because seals obtain less energy when prey are only partially consumed, a greater number of prey must be eaten to meet metabolic demands. Selective feeding of winter skate was not simulated because there have been no reports of incomplete consumption of skates by seals and because, we find that there is a high probability that seal predation could explain skate $M$ even if consumption is complete (see 'Results: Probability of explaining $M$ as a function of seal diet consumption'). Estimates of viscera mass and headless-body mass as a function of fish body length were required for cod and white hake to simulate partial consumption. The data required to estimate seasonal relationships between cod body length and viscera mass have been collected since 1991 (Schwalme \& Chouinard 1999, Fisheries and Oceans Canada unpubl. data). Similar data for white hake were unavailable so we used the relationships for cod, adjusted proportionately for differences in the mean mass-at-length between the 2 species. Intra-season variability in the relationships was again estimated using bootstrapping of the observed values. To account for the consumption of the flesh surrounding the viscera, the estimated mass was multiplied somewhat arbitrarily by 1.3. Data on the mass of southern Gulf cod and white hake heads were unavailable. We used Gildberg's (2004) estimate for cod heads: $21 \pm 2 \%$ (SE) of total body mass.

\section{Fish energy content}

Species-specific values for fish energy density (ED; $\mathrm{kJ} \mathrm{g}^{-1}$ body mass) were obtained from the literature (Table 1). A value for little skate Leucoraja erinacea was used for winter skate. Values for all 3 species, when consumed whole, were assumed to follow normal distributions with a CV of $15 \%$ (based on results for cod in Lawson et al. 1998). ED values for cod viscera were derived using the seasonal relationships between viscera and total mass (section 'Methods: Simulation components-Partial consumption of fish prey' above) and assuming that the rejected portion had the ED values of cod fillets (Ingenbleek 2006). Because the relationship between viscera and total 
mass is allometric, the resulting viscera ED values were log-normally distributed (Table 1). In the absence of specific data, these values were also used for belly-bitten white hake. ED values for headless cod and white hake were assumed to be $5 \%$ higher than whole fish to account for the fact that the rejected fraction (the head) is less energy-dense. Seasonal variation in fish ED was not incorporated in the simulation because the magnitude of change is relatively small ( $\leq 3 \%$ ) (Beck et al. 2007).

\section{Spatio-temporal overlap among all species}

Bottom-trawl surveys of the sGSL and neighbouring areas have been conducted in most months and were used to characterise the monthly spatial distribution of the 3 fish species. (Note that these additional surveys were used to assess distribution and were not used in the estimation of demographic parameters in section 'Methods-Simulation components: Fish abundance, natural mortality and body size' above). These surveys include seasonal surveys undertaken in 1986-1987 (southeastern Gulf of St. Lawrence) and 1989-1992 (southwestern Gulf), January surveys conducted annually from 1994 to 1997 in the Cabot Strait, annual summer surveys of the Northumberland Strait from 2004 to 2006, and recent data (2004 to 2006) from surveys of the entire sGSL conducted in August and in September (Clay 1991, Darbyson \& Benoît 2003, Swain et al. 2006, Hurlbut et al. 2010, Savoie \& Surette 2010).

The spatial distribution of each species was summarised using survey strata as the spatial unit of interest (Fig. 6). These strata are based on bathymetry, which also largely defines fish distribution. Individual strata comprise on average $\sim 4 \%$ of the study area, which is probably the finest reasonable scale $\left(1000 \mathrm{~s} \mathrm{~km}^{2}\right)$ at which to characterise distribution in our study. For each of the months from November to June, fish distribution was characterised as occupancy (i.e. equal density of fish among occupied strata) because there were no recent surveys in those months to inform a more refined depiction of distrib-
Fig. 6. Gadus morhua, Urophycis tenuis and Leucoraja ocellata. Summary of the geographic distribution of the 3 fish species as used in the simulation. Left panels: occupancy of each fish species at the stratum scale during winter (dark grey shading) and spring and autumn (light grey shading); strata occupied from autumn to spring are also shown (shaded black). Right panels: distribution of density for each fish species based on summer bottom-trawl surveys; incrementing grey shading represents increasing density based on the 10th (lightest grey), 25th, 50th, 75th and 90th (black) percentiles for nonzero density for each species
Occupancy in autumn, winter and spring

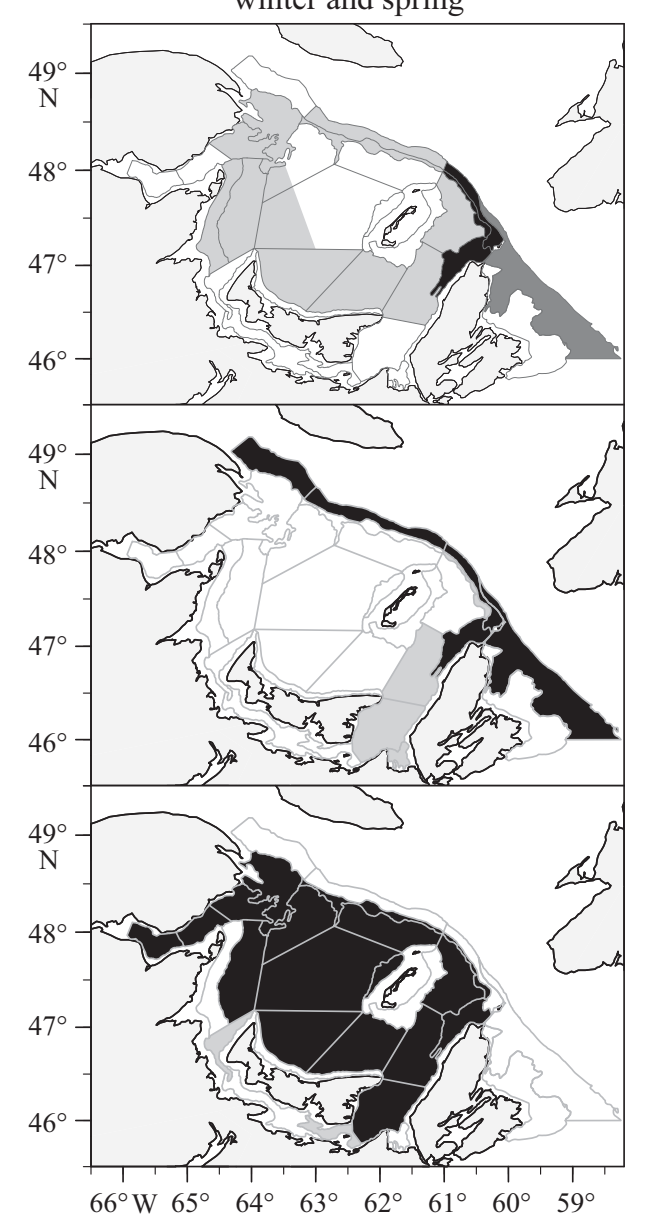

Fish density in late summer

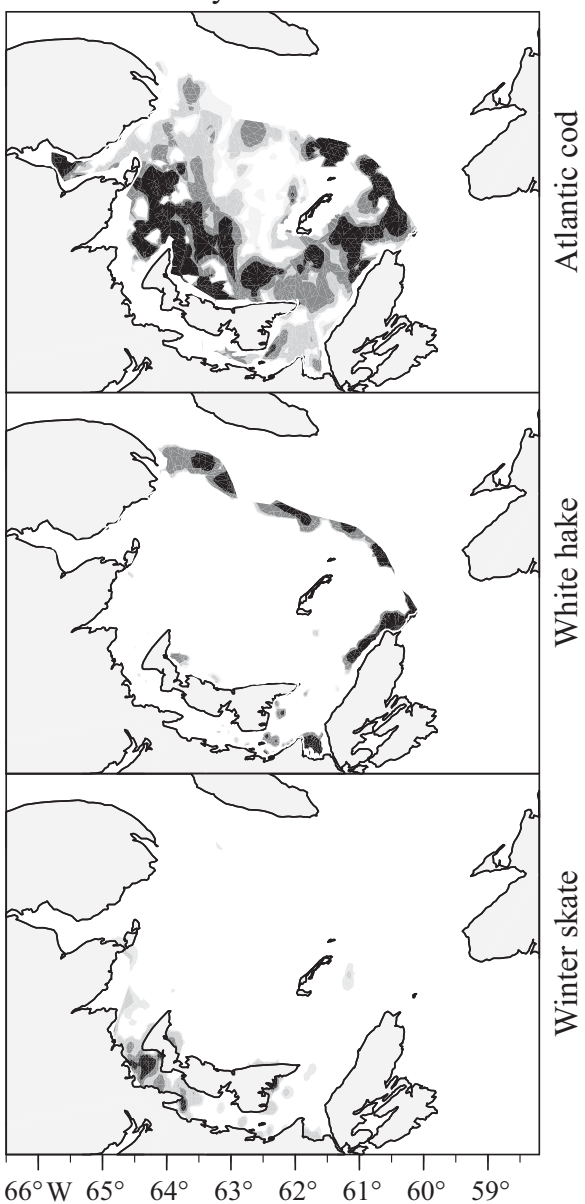


ution (Fig. 6). Strata in which $\geq 10 \%$ of survey tows caught a given species were considered occupied by that species. The distribution of the fish species observed in August and September surveys in 20042006 was used to characterise the distribution among strata for July-August and September-October respectively. Because detailed recent information on distribution was available for those months, fish distribution was characterised based on observed densities in each stratum. Furthermore, bootstrapping of survey sets within strata was used to simulate the observation error associated with fish distribution during the summer and early autumn.

The seasonal distribution of the fishes can be summarised as follows (our Fig. 6; for more details see Clay 1991 and Darbyson \& Benoît 2003). sGSL cod overwinter in the deeper waters of Sydney Bight and along the southeastern slope of the Laurentian Channel (Fig. 1). In about April, cod migrate into the sGSL following the northwestern coast of Cape Breton Island as well as along the slope of the channel. They historically distributed themselves broadly throughout the sGSL from the late spring to mid-autumn, though concentrations in the centre of the Magdalen shallows have decreased substantially since the mid1990s. The return migration to overwintering grounds now occurs in November (Comeau et al. 2002). White hake overlap substantially with cod during the winter. Spring migration occurs later in May, with some hake moving to coastal areas in the southernmost portion of the sGSL and others remaining in the Laurentian Channel (Clay 1991). The autumn migration to overwintering grounds appears to occur in late November and early December. Finally, winter skate appear to be broadly distributed over the Magdalen shallows during the winter (Darbyson \& Benoît 2003). In late May and early June they migrate to the shallow areas of the sGSL, with important concentrations in the coastal waters of Prince Edward Island and New Brunswick (Swain et al. 2006). The autumn migration is nearly complete by mid-November.

Satellite tags deployed between 1993 and 2010 on 131 grey seals from the Sable Island herd (mainly young-of-the-year and individuals 8+yr old) and 56 from the Gulf herd (including 27 juveniles) provide information on seasonal distribution and movements (Goulet et al. 2001, Breed et al. 2006, Harvey et al. 2008). The average seal was tracked for about 7 mo, and for any given month there were data for 7 to 107 tagged Sable herd seals and 5 to 44 tagged Gulf herd individuals. A state-space model described by Jonsen et al. (2005) was used to handle observation errors in raw Argos satellite-derived positions and to normalise the number of positions reported per day per seal to 3 (Breed et al. 2006, Harvey et al. 2008).

The seasonal distribution of grey seals can be briefly described as follows (Fig. 4). Grey seals are on their breeding grounds during December to February, after which they disperse to feed. During moulting, animals spend more time ashore, dispersing once moulting is complete. Gulf animals may disperse to the Scotian Shelf, or other areas in the Gulf and estuary of the St. Lawrence, and Sable animals may disperse throughout the Scotian Shelf or move into the Gulf (Stobo et al. 1990, Lavigueur \& Hammill 1993, Goulet et al. 2001, Austin et al. 2006, Breed et al. 2006, Harvey et al. 2008).

Previous analyses of the tracking data have revealed sex- and stage-dependent differences in grey seal movements (Breed et al. 2006, Harvey et al. 2008). The respective monthly distribution of juvenile, adult male and adult female grey seals from each of the Sable and Gulf herds (henceforth, seal groups) was summarised as the proportion of normalised positions occurring each month in each bottom-trawl survey stratum. These monthly distributions were assumed to be representative of the populations of each seal group for 2005. In creating these summaries, data for a particular seal in a given month were only retained if that seal was tracked for at least $10 \mathrm{~d}$. Because there were few tagged seals in the spring, data from the months adjoining a month of interest were pooled. Variability in seal distributions was estimated by bootstrapping the satellite tracking data, treating individual seals within seal groups as sampling units.

There has been no satellite tracking of Coastal Nova Scotia grey seals, though some of them likely spend some time foraging where sGSL fish occur. We assumed that the movement patterns of these seals likely reflect those observed in the other 2 herds, though they are perhaps more like Sable Island seals. A portion, $P_{\text {Coastal, }}$ of the Coastal Nova Scotia herd was assumed to have a monthly distribution identical to Sable Island grey seals, while the remainder, 1 $P_{\text {Coastal, }}$ adopted the distribution of Gulf seals. $P_{\text {Coastal }}$ was somewhat arbitrarily defined to vary uniformly over the interval 0.3 to 1.0 (Table 1 ).

\section{Predation given seal-fish overlap}

Within a stratum occupied by seals, we assumed that consumption of each fish species was proportional to their respective biomasses in that stratum. 
Though we acknowledge the multitude of possible multi-species functional responses relating prey availability to seal consumption (e.g. Koen-Alonso 2007), this was the simplest assumption to make in the absence of strong data on grey seal prey preference, the abundance of other prey in each cell, and possible prey switching. However, while this functional response results in proportional consumption at the local stratum scale, differential patterns in the spatial distribution of all animals considered in the simulation and bioenergetic limits on seal consumption mean that the functional response is non-linear at the population scale. It is ultimately at this population scale that assumptions about functional responses are important for population dynamics modelling and where the assumption of a Type I multi-species functional response may be most tenuous (e.g. Mackinson et al. 2003, Koen-Alonso \& Yodzis 2005, Matthiopoulos et al. 2008).

Fish of different sizes were also consumed in proportion of availability in the simulations. This was assumed because current estimates of prey size composition in grey seal diets in the sGSL are considered unreliable. Diet samples collected during the summer and the autumn reflect feeding mainly in shallow waters (Fig. 1), where the smaller individuals of the species of interest are most prevalent and larger individuals are rarer or absent (Macpherson \& Duarte 1991, Swain 1993). This could explain the high proportion of smaller individuals in sampled seal diets (our Fig. 7; Hammill et al. 2007). In contrast, winter sampling in an area where both small and large cod congregate (Fig. 1, location denoted by a star) suggests that seals may select larger fish (Fig. 7).

For simplicity, the biomass of each fish species remaining at the end of each month following seal consumption was distributed proportionately among the strata those fish occupy in the following month.

\section{Simulation scenarios and output metrics}

Separate scenarios were simulated to account for the possible partial consumption of cod and white hake, either by belly-biting or head-rejection. In each case, we simulated different proportions of fish eaten partially, ranging from 0 to 1 and incremented by 0.1 between simulations. Though some, but not all, consumed cod and hake are eaten partially in nature, the true proportions are not known, so we simulated proportions over the full range for illustration purposes.
Each scenario comprised 5000 iterations of the simulation. From the resulting set of model realisations, we calculate 3 properties of interest. The first is the average monthly potential consumption of each fish species by seals (i.e. mean consumption in the absence of alternate prey). This is a measure of the scope for a predation effect based solely on the constraints of grey seal energy demands, fish energy content and overlap between seals and individual fish species. The second property of interest is the probability that seal predation can explain certain fractions of fish $M$ given different assumptions for seal diets, conditional on the various assumptions of the simulation structure and parameters. For a given fish species, this was calculated as the proportion of realisations in which the simulated consumption resulted in a mortality that was equal to or exceeded a given proportion of the randomly drawn $M$ for that species. Separate probabilities were calculated for the 2 age groups of cod because they had different $M$ values. The third property of interest was the mean seal diet composition (\%) implied by different proportions of fish species $M$, at different levels of partial consumption of fish. This was calculated specifically for those seals that overlap with a given fish species, and also at the seal herd level. The estimated diet of overlapping seals in the simulation provides an indication of the degree to which total consumption is constrained by spatial overlap.

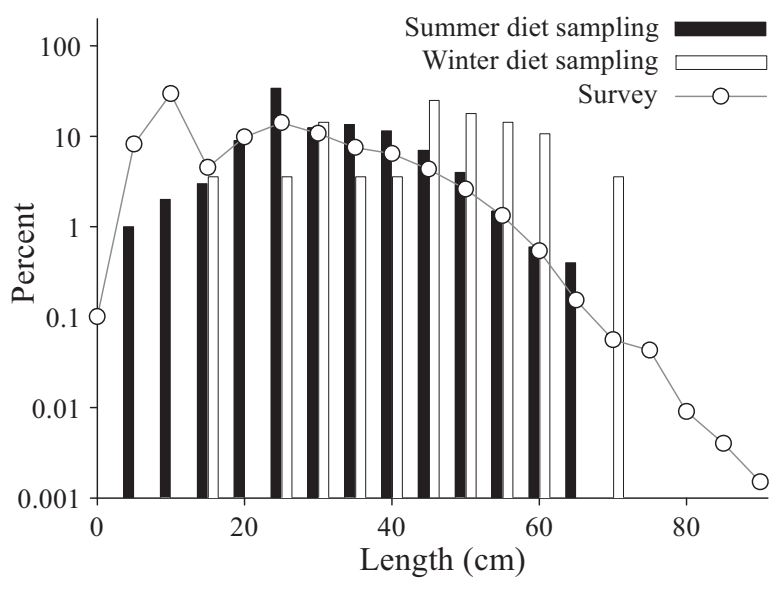

Fig. 7. Gadus morhua and Halichoerus grypus. Frequency distribution of southern Gulf of St. Lawrence cod lengths in the 2005 population, and in grey seal diet samples collected during spring-summer and in the winter of 2008 (location denoted by a star in Fig. 1). The population frequency distribution is based on catchability-adjusted estimates from the annual September survey. Note that the percentage axis is on a $\log$-scale 


\section{RESULTS}

\section{Total potential consumption}

For the 3 fish species, the highest potential consumption occurred during the summer months (Fig. 8). This result may in part be because we allowed fish density to vary among occupied strata in those months based on the results of summer bottomtrawl surveys, and if seal densities were greatest in strata where fish densities were high. In 2005, an average of around 2600 tonnes (t) $\mathrm{mo}^{-1}\left(31044 \mathrm{t} \mathrm{yr}^{-1}\right)$ of whole age $5+\mathrm{yr}$ cod could potentially have been eaten by seals, based on the estimated overlap in the spatial distributions of seals and fish. In comparison, the point estimate of cod loss due to $M$ that year was about $28126 \mathrm{t}$ (Table 2). In all but the summer months, cod overlapped overwhelmingly with grey seals from the Gulf herd (Fig. 8). Potential consumption of adult white hake by seals was estimated to average $2350 \mathrm{t} \mathrm{mo}^{-1}$ in 2005 ( 28300 $\mathrm{t}$ for the year) (Fig. 8), while estimated losses due to $M$ for the year were $3471 \mathrm{t}$ (Table 2). For winter skate, Gulf herd seals contribute almost exclusively to an average potential consumption of $6100 \mathrm{t} \mathrm{mo}^{-1}$, which is more than an order of magnitude larger than the estimated annual loss to $M$.

A global sensitivity analysis of the contribution of input parameter variability to total variability in seal consumption was undertaken using a general linear model (Saltelli et al. 2000). Approximately $28 \%$ of variability in consumption was due to variability in seal abundance and overlap with fish, $40 \%$ due to variability in the bioenergetics model, with the remainder due to variability in the various other inputs.

\section{Probability of explaining fish $M$ as a function of seal diet composition}

Even in the absence of partial consumption by seals, there was a 0.5 probability of explaining $\sim 70 \%$ of $M$ in cod aged 5 to $10 \mathrm{yr}$ and a very high probability ( $\geq 0.95$ ) of explaining $\sim 20 \%$ of $M$ (Fig. 9a). To explain $70 \%$ of $M$ required that the diet of grey seals that overlapped spatially with these cod be dominated by them ( 60\% in the diet) (Fig. 10). This however translates to about $15 \%$ of sGSL cod ages 5 to $10 \mathrm{yr}$ in the average diet of Gulf seals (Fig. 10) and $3 \%$ in the diet of Sable Island seals (not shown).

A predation effect was slightly more likely for cod aged $11+\mathrm{yr}$ in the absence of partial consumption, with probabilities of 0.5 and 0.95 of explaining

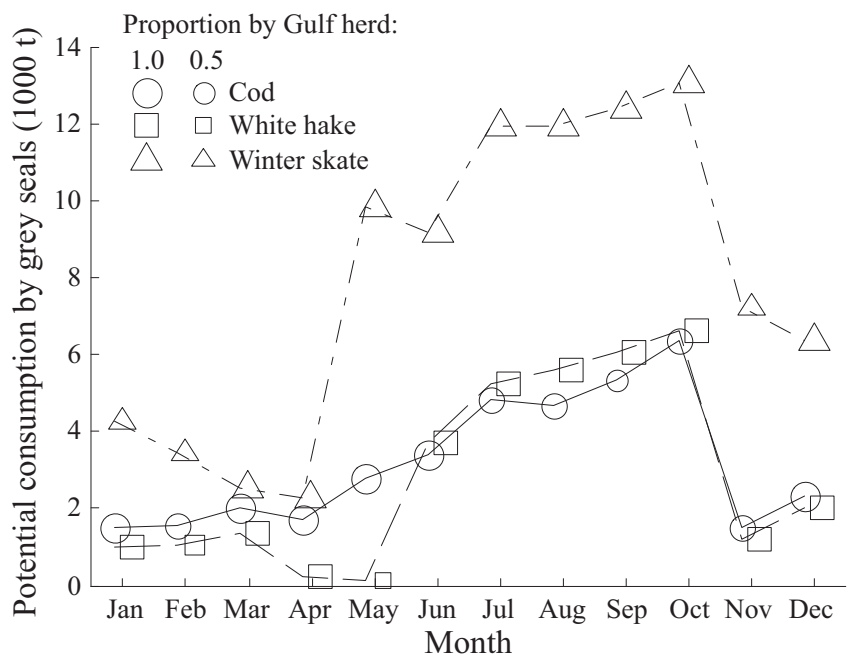

Fig. 8. Gadus morhua, Urophycis tenuis, Leucoraja ocellata and Halichoerus grypus. Average monthly potential consumption of southern Gulf of St. Lawrence cod, white hake and winter skate by grey seals. Symbol size indicates the relative contribution of the Sable Island and Gulf herds to potential consumption, as indicated in the key. Note that symbols have been slightly offset horizontally for clarity

Table 2. Gadus morhua, Urophycis tenuis and Leucoraja ocellata. Average 2005 beginning-of-the-year fish biomass and total biomass loss implied by the estimated (empirically derived) natural mortality

\begin{tabular}{|lrc|}
\hline Species & Biomass (t) & Biomass loss (t) \\
\hline Atlantic cod, ages 5+ yr & 53883 & 28126 \\
White hake, ages 5-7 yr & 4078 & 3471 \\
Winter skate adults & 816 & 369 \\
\hline
\end{tabular}

$\sim 80$ and $50 \%$ of $M$, respectively (Fig. 9c). To explain $80 \%$ of their $M$, age $11+$ yr cod must comprise $\sim 3.3 \%$ of the diet of overlapping grey seals, and $<0.8 \%$ of the mean diet of the Gulf herd (Fig. 10).

Consumption of whole age $3+\mathrm{yr}$ white hake by grey seals could explain $\sim 40$ and $15 \%$ of $M$ with respective probabilities of 0.5 and 0.95 . The 0.5 probability would be achieved if white hake comprise around $8 \%$ of the diet of overlapping seals and $2.5 \%$ and $<0.5 \%$ of the respective mean diets of the Gulf and Sable Island herds (Fig. 10; results not shown for the Sable Island herd diet). Predation of white hake is heavily constrained by considerable spatial overlap with adult cod and our assumption of a proportional functional response, as is evident from the large potential consumption of hake noted previously (Fig. 8). White hake consumed whole would need to comprise about 12 and $4 \%$ of the diets of overlapping and Gulf herd grey seals, respectively (Fig. 10) to 
Fig. 9. Gadus morhua, Urophycis tenuis and Halichoerus grypus. Contours of the probability from the simulation that grey seal predation can explain different proportions of fish natural mortality, $M$, (ordinate) as a function of different proportions of fish consumed only partially (abscissa), for $(a, b)$ age 5-10 yr cod, $(\mathrm{c}, \mathrm{d})$ age $11-15$ yr cod or $(e, f)$ white hake, consumed partially by either $(a, c, e)$ belly-biting or $(b, d, f)$ head-rejection. The isoprobability contours are drawn using incrementing grey shading as indicated in (f), e.g. probability $=0.25$ (lightest grey) to probability $=0.95$ (black)

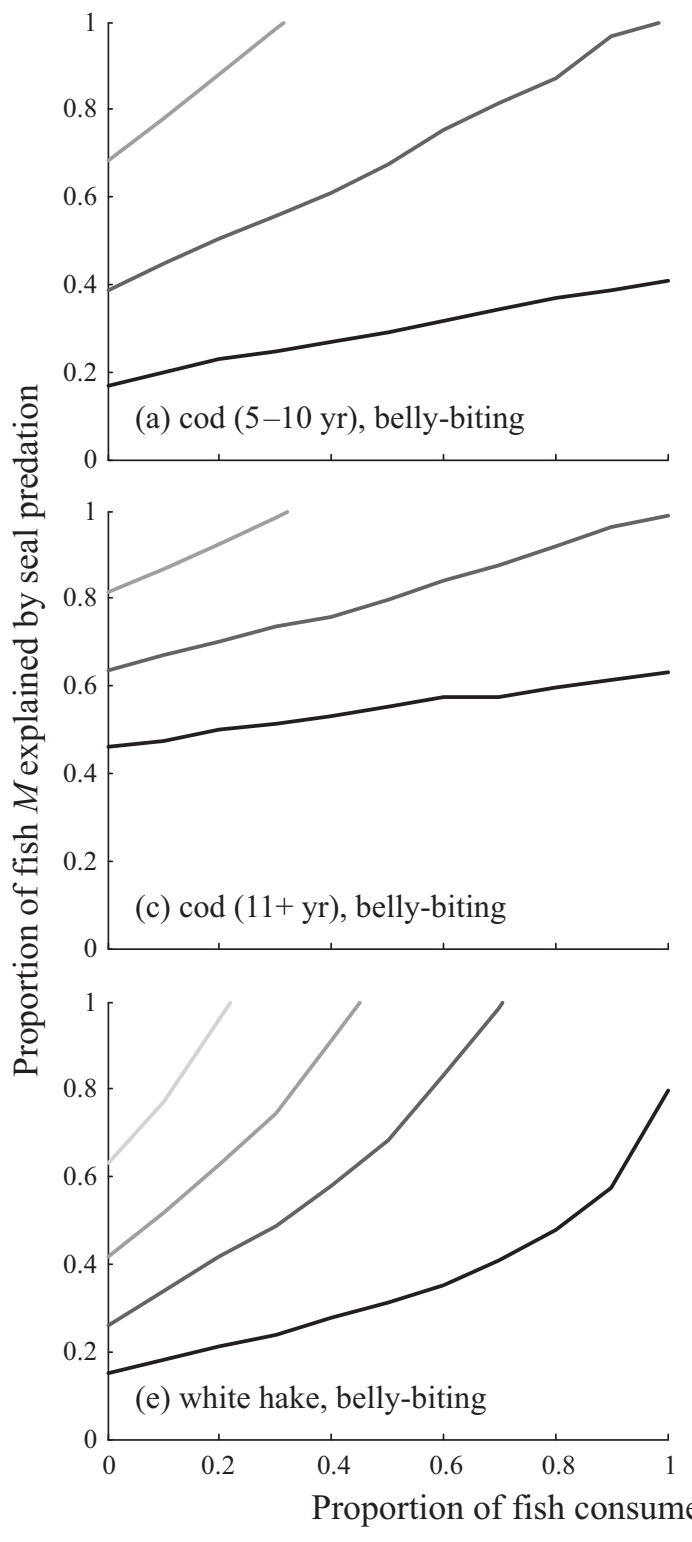

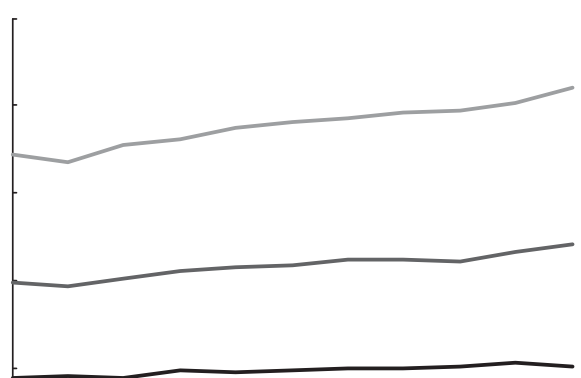

(b) $\operatorname{cod}(5-10 \mathrm{yr})$, head-rejection

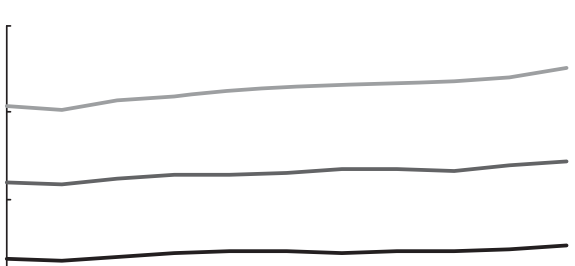

(d) $\operatorname{cod}(11+y r)$, head-rejection

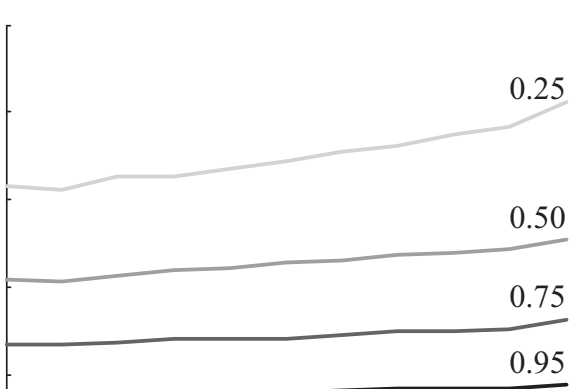

(f) white hake, head-rejection

$\begin{array}{llllll} & 1 & 1 & 1 & \\ 0 & 0.2 & 0.4 & 0.6 & 0.8 & 1\end{array}$ explain all of the $M$ in excess of the level estimated for years prior to 1985 (Fig. 2c).

For white hake and both cod age groups (5-10 and $11+y r)$, the probability that grey seal predation explains $M$ increases as the seals include more partially consumed fish in their diet (Fig. 9). The increases are most pronounced when partial consumption takes the form of belly-biting, because fewer $\mathrm{kJ}$ are obtained from each killed fish. The probability that a given proportion of $M$ is explained by grey seals increases by $50 \%$ if $10-25 \%$ of white hake and $25-50 \%$ of cod are consumed by belly-biting. At these levels, these fish also comprise 15 to $30 \%$ less of the total energy required by grey seals, compared to the scenario where seals always consume whole fish (Fig. 10). Increasing the proportion of fish that are consumed partially by head-rejection has considerably less impact on the probability of explaining $M$ (Fig. 9). Compared to a situation where fish are all consumed whole, if seals consume $50 \%$ of cod and white hake by head-rejection, the proportion of $M$ that can be explained at a given probability level increases by $\sim 10 \%$.

Given the very high potential for consumption of adult winter skate by grey seals (Fig. 8), all of winter skate $M$ was explained by predation in every simulation undertaken (results not shown). To explain all of their $M$, adult winter skate must comprise no more than $0.6 \%$ of the diet of the grey seals that overlap spatially with them, and no more than $0.2 \%$ and $<0.05 \%$ of the respective mean diets of the Gulf and Sable Island herds (Fig. 11). 


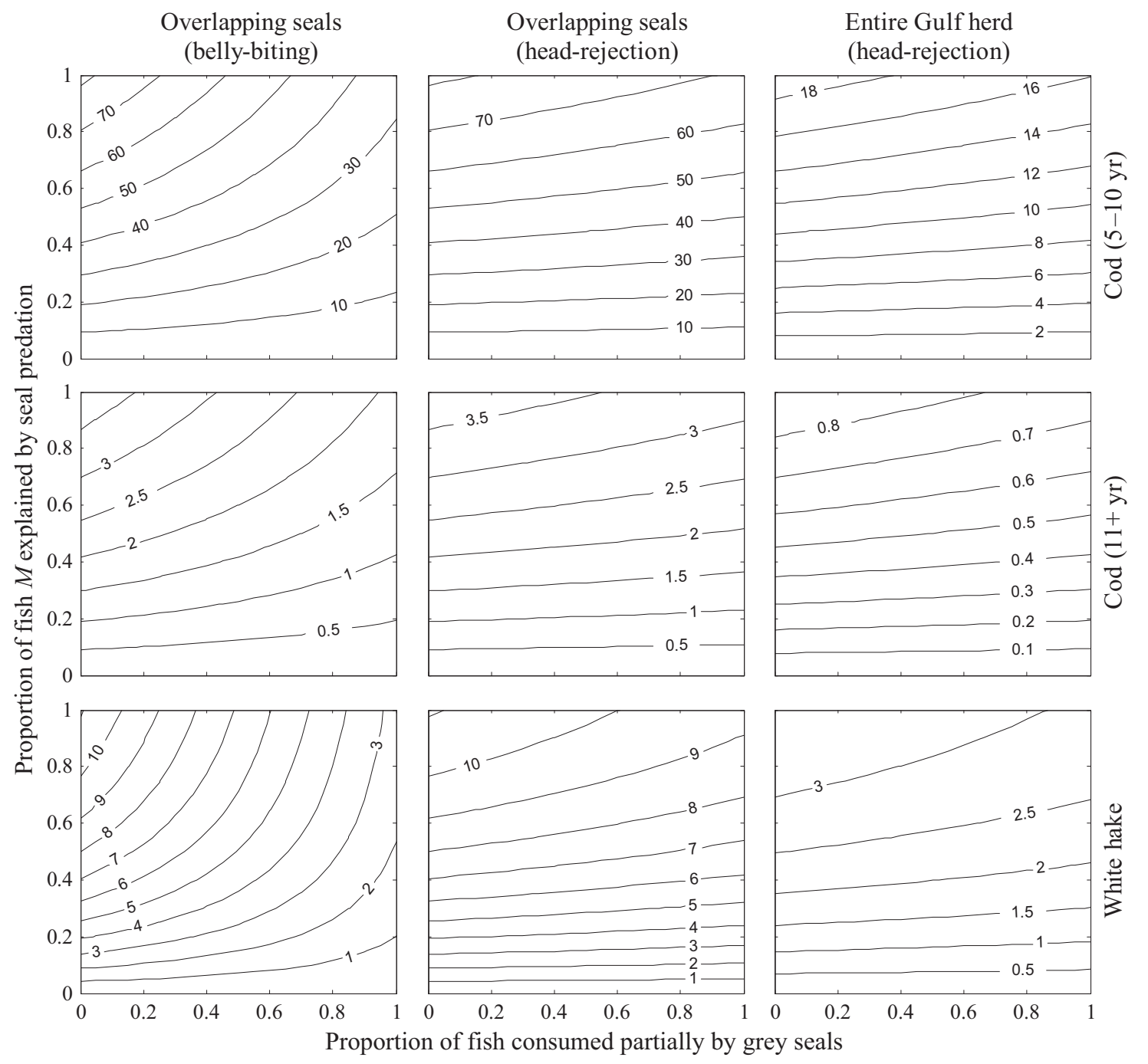

Fig. 10. Gadus morhua, Urophycis tenuis and Halichoerus grypus. Contours of the grey seal diet composition (\% of total diet) required to explain different proportions of fish natural mortality $M$ (ordinate) as a function of different proportions of fish consumed only partially (abscissa), for age 5-10 yr cod (upper panels), age 11-15 yr cod (middle panels) or white hake (lower panels). The composition of the diet of seals overlapping with the fish species/age group in question is shown for the scenarios involving belly-biting (left column) and head-rejection (centre column) of prey. The composition of the average diet of a Gulf grey seal in the head-rejection scenario is shown in the right column

\section{DISCUSSION}

To date, modelling studies of the effect of seals on NW Atlantic cod populations (e.g. Trzcinski et al. 2006, Chassot et al. 2009) or the ecosystems in which they reside (e.g. Bundy \& Fanning 2005, Savenkoff et al. 2007) have been parameterised using the species and size composition of fish observed in the available seal diet samples. While these studies have concluded that seals (harp or grey seals, depending on the ecosystem) have impeded the recovery of collapsed populations to a degree, the extent of this effect is estimated to be small and for many stocks a substantial proportion of the natural mortality of large fish remains unexplained. However, these results are largely driven by the estimated seal diets, which we suggest may underestimate the consumption of larger fish. Nevertheless, indirect evidence points to an effect of grey seals on sGSL marine fish stocks. Changes in the species composition of the sGSL marine fish community are consistent with an effect of grey seal predation, and basic consumption modelling suggests that removals of fish by grey seals may have replaced the extraction formerly imposed by fisheries, which are now closed or severely scaled back compared to the 1970s and 1980s (Benoît \& Swain 2008, Savenkoff et al. 2008). Although numerous other hypotheses have been 


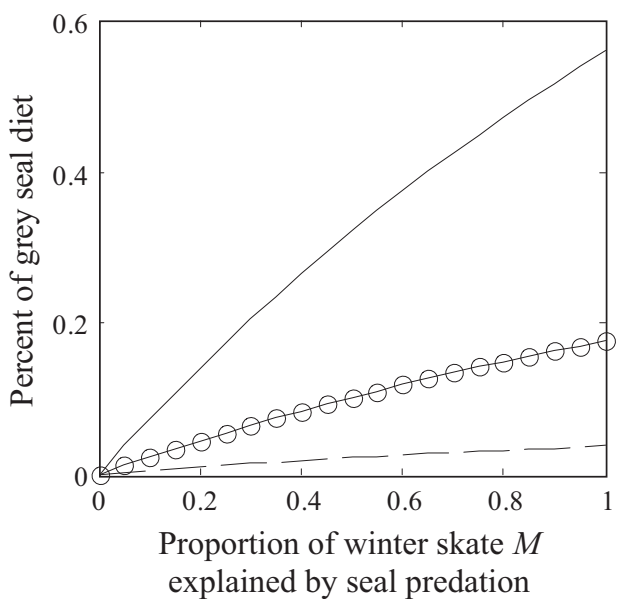

Fig. 11. Leucoraja ocellata and Halichoerus grypus. Percentage of winter skate in the grey seal diet required to explain different proportions of winter skate natural mortality, $M$. Shown is the required diet composition for the average Sable Island (dashed line) or Gulf ( $($ ) grey seal, and for Gulf grey seals overlapping spatially and seasonally with winter skate (solid line)

proposed to explain elevated $M$ of adult cod, predation by grey seals remains the hypothesis with the greatest support (Bowen et al. 2009, Swain 2011, Swain et al. 2011). Finally, unusually high adult $M$ is a common feature among all Canadian cod stocks located to the south of the Laurentian Channel, the area with the greatest overlap with NW Atlantic grey seals. Conversely, $M$ does not appear to currently be as elevated to the north of the Channel, where grey seals are less abundant.

Our approach shows that the conditions exist for grey seal predation to comprise a significant component of $M$ among large cod, hake and skate, given the assumptions of our model. We find that while the consumption of cod aged 5 to $10 \mathrm{yr}$ in the simulation was particularly constrained by spatial overlap and seal bioenergetics, an important portion of their $M$ $(\sim 20 \%)$ could be explained with high certainty $(0.95$ probability) even in the absence of belly-biting. Furthermore, this result was obtained even if these cod formed only $5 \%$ of the average diet of Gulf seals. In the simulation, there was also strong potential for seal predation to explain the elevated $M$ of white hake, provided grey seals had some preference for them relative to ages 5-10 yr cod. In contrast, there was abundant scope for grey seals to consume winter skate in the simulations, regardless of the abundance of other species. Jointly, the results of our modelling suggest that, to the extent that the simulation assumptions are correct, predation by grey seals can account for the elevated adult mortality of the 3 fish species concerned. Jointly, the sGSL populations of these 3 fish species need to comprise only about $20 \%$ of Gulf and $3.5 \%$ of Sable Island grey seal diets to explain most of their $M$.

Attributing a large component of fish $M$ to seal predation becomes more likely if seals consume some of their prey only partially, particularly if seals only consume the viscera of fish. Partial consumption of fish, particularly belly-biting, is believed by fish harvesters to be common, though quantitatively documenting its frequency has been difficult except for seals that forage near shore (e.g. Lilly \& Murphy 2004, Hauser et al. 2008), in and around fishing gear (e.g. Moore 2003), or in captivity (e.g. Phillips \& Harvey 2009). Animal-borne cameras (e.g. Marshall 1998, Bowen et al. 2002) might provide new insights into the size-frequency and the prevalence of incomplete consumption of large demersal fishes eaten by grey seals, but the key will be in obtaining a representative sample. Further captive-feeding trials with choices of live prey might also be beneficial.

There are specific conditions under which partial consumption of prey is an optimal predation strategy (e.g. Cook \& Cockrell 1978, Sih 1980, Penry 1993). A predator consuming an individual prey item must be able to selectively feed on portions of differing net energetic value (i.e. energy gained relative to processing cost). There must also be a net energetic benefit of leaving an unfinished prey item to find and capture a subsequent prey. An optimal foraging model of partial consumption predicts that as prey density decreases, increasing the costs of prey acquisition, predators should consume increasing proportions of individual prey items (Sih 1980). The model predictions and the conditions under which partial consumption is an optimal strategy were borne out in a study of bears feeding on salmon (Gende et al. 2001). The conditions for partial consumption may also exist for cod and white hake in the southern Gulf. First, energy density is not uniform within their bodies: depending on the season, the viscera of adult cod comprise on average between 11 and $16 \%$ of total body mass but between 30 and $43 \%$ of total body energy content. Second, positive abundance-occupancy relationships mean that local fish density can remain high even as abundance decreases (e.g. Swain \& Sinclair 1994). It may therefore still be profitable for seals that target aggregations to only partially consume individual prey despite declining fish abundance. Larger fish may be more likely to be partially eaten because their energy-dense parts should be easier to target and their bones more costly to process in terms of handling time, compared to smaller 
fish. Nevertheless, the presence of alternative and potentially more profitable prey in areas occupied by cod could negate such expectations.

If predation by grey seals contributes significantly to adult cod and white hake $M$, our simulations suggest that the contribution of these species to average diet will be relatively small and highly clustered in the small proportion of seals that overlap spatially with them. Individual diet specialisation has been observed in many other species (reviewed by Bolnick et al. 2003) and may also occur in grey seals (Beck et al. 2007, Tucker et al. 2007). Estimating a reliable average diet in the face of diet specialisation and a diverse prey set requires a large sample that is spatially and seasonally representative. For species such as winter skate, which would occur only at trace levels in the diet and are unlikely to be detected by traditional hard-parts analyses, predation is likely to go undetected (but see results based on chemical analyses in Beck et al. 2007).

Though our simulations aimed to capture a number of sources of uncertainty related to consumption by seals and to fish losses, potential biases related to the monthly geographic distributions of all species likely remained. For the fishes, monthly distributions other than in summer and early autumn were inferred from past surveys conducted during periods of higher abundance and therefore may differ from present distributional patterns. Furthermore, by assuming that distribution is uniform over the occupied area in non-summer months, consumption may have been underestimated if grey seals concentrate in highdensity areas or overestimated if they aggregate in low-density areas. For grey seals, transmitters were deployed in locations where they could be captured and not necessarily where animals were distributed. It is therefore unclear to what degree distributional patterns inferred from the few tagged individuals are representative of the respective herds.

Two important components of predator behaviour that determine prey consumption are decisions related to which foraging areas to occupy and decisions concerning prey selection in the chosen foraging areas. The simulations only dealt with the former component, which shapes the potential for predation. However, the predator's functional response, when confronted with a choice of sizes and species of prey, can largely influence the resulting diet. This is an information gap that can be filled by simultaneous sampling of seal diets and the prey field (e.g. Smout \& Lindstrøm 2007). At present, the simulations therefore cannot verify the hypothesis that grey seal predation is an important contributor to large fish $M$.
Rather, they can only establish the degree to which the hypothesis is plausible, given constraints on food ingestion by seals, overlap between species and species abundances. The simulations are therefore another approach to increase our understanding of the ecosystem-level impacts of population increases in this generalist upper-trophic-level predator. However, the largest challenge ahead will be in better understanding the diverse indirect interactions in the food webs (e.g. Punt \& Butterworth 1995, Walters \& Kitchell 2001, Wirsing et al. 2008) of which grey seals are an important component. It is these interactions in particular that make predicting the outcome of possible management actions very difficult (Bax 1998, Yodzis 1998, 2001). Quantifying these interactions means obtaining representative diets of all interacting species, highlighting again the need for more accurate estimates of grey seal prey composition at the population scale.

Acknowledgements. This paper benefited from careful reviews provided by T. Hurlbut, R. Morin, V. Trenkel and anonymous reviewers as well as by comments from participants at a Fisheries and Oceans Canada (DFO) workshop on impacts of seals on fish populations in eastern Canada (Halifax, Nova Scotia, November 24-28, 2008).

\section{LITERATURE CITED}

Austin D, Bowen WD, McMillan JI, Iverson SJ (2006) Linking movement, diving, and habitat to foraging success in a large marine predator. Ecology 87:3095-3108

Bax NJ (1998) The significance and prediction of predation in marine fisheries. ICES J Mar Sci 55:997-1030

Beck CA, Bowen WD, Iverson SJ (2003) Sex differences in the seasonal patterns of energy storage and expenditure in a phocid seal. J Anim Ecol 72:280-291

$>$ Beck CA, Iverson SJ, Bowen WD, Blanchard W (2007) Sex differences in grey seal diet reflect seasonal variation in foraging behaviour and reproductive expenditure: evidence from quantitative fatty acid signature analysis. J Anim Ecol 76:490-502

Benoît HP (2006) Standardizing the southern Gulf of St. Lawrence bottom-trawl survey time series: results of the 2004-2005 comparative fishing experiments and other recommendations for the analysis of the survey data. DFO Can Sci Advis Sec Res Doc 2006/008. Fisheries and Oceans Canada, Ottawa

> Benoît HP, Swain DP (2008) Impacts of environmental change and direct and indirect harvesting effects on the dynamics of a marine fish community. Can J Fish Aquat Sci 65:2088-2104

Benoît HP, Swain DP (2011) Changes in size-dependent mortality in the southern Gulf of St. Lawrence marine fish community. DFO Can Sci Advis Sec Res Doc 2011/ 039. Fisheries and Oceans Canada, Ottawa

Benoît HP, Swain DP, Hammill MO (2011) A risk analysis of the potential effects of selective and non-selective reductions in grey seal abundance on the population status of two species at risk of extirpation, white hake and winter 
skate in the southern Gulf of St. Lawrence. DFO Can Sci Advis Sec Res Doc 2011/033. Fisheries and Oceans Canada, Ottawa

Bolnick DI, Svanbäck R, Fordyce JA, Yang LH, Davis JM, Hulsey CD, Forister ML (2003) The ecology of individuals: incidence and implications of individual specialization. Am Nat 161:1-28

Bousquet N, Cadigan N, Duchesne T, Rivest LP (2010) Detecting and correcting underreported catches in fish stock assessment: trial of a new method. Can J Fish Aquat Sci 67:1247-1261

Bowen WD (2000) Reconstruction of pinniped diets: accounting for complete digestion of otoliths and cephalopod beaks. Can J Fish Aquat Sci 57:898-905

Bowen WD, Tully D, Boness DJ, Bulheier BM, Marshall GJ (2002) Prey-dependent foraging tactics and prey profitability in a marine mammal. Mar Ecol Prog Ser 244: 235-245

Bowen WD, McMillan J, Mohn R (2003) Sustained exponential population growth of grey seals at Sable Island, Nova Scotia. ICES J Mar Sci 60:1265-1274

Bowen WD, McMillan JI, Blanchard W (2007) Reduced population growth of gray seals at Sable Island: evidence from pup production and age of primiparity. Mar Mamm Sci 23:48-64

Bowen WD, Hammill MO, Koen-Alonso M, Stenson G, Swain DP, Trzcinski K (2009) Seal Impacts Workshop II. Can Sci Advis Sec Proc Ser 2009/020. Fisheries and Oceans Canada, Ottawa

Breed GA, Bowen WD, McMillan JI, Leonard ML (2006) Sexual segregation of seasonal foraging habitats in a non-migratory marine mammal. Proc R Soc B Biol Sci 273:2319-2326

> Bundy A, Fanning LP (2005) Can Atlantic cod (Gadus morhua) recover? Exploring trophic explanations for the non-recovery of the cod stock on the eastern Scotian Shelf, Canada. Can J Fish Aquat Sci 62:1474-1489

> Castellini MA, Kooyman GL, Ponganis PJ (1992) Metabolic rates of freely diving Weddell seals: correlations with oxygen stores, swim velocity and diving duration. J Exp Biol 165:181-194

Chassot E, Duplisea D, Hammill M, Caskenette A, Bousquet N, Lambert Y, Stenson G (2009) Role of predation by harp seals Pagophilus groenlandicus in the collapse and non-recovery of northern Gulf of St. Lawrence cod Gadus morhua. Mar Ecol Prog Ser 379:279-297

Chouinard GA, Swain DP, Hammill MO, Poirier GA (2005) Covariation between grey seal (Halichoerus grypus) abundance and natural mortality of cod (Gadus morhua) in the southern Gulf of St. Lawrence. Can J Fish Aquat Sci 62:1991-2000

Clay D (1991) Seasonal distribution of demersal fish (Osteichthyes) and skates (Chondrichthyes) in the southeastern Gulf of St. Lawrence. In: Therriault J-C (ed) The Gulf of St Lawrence: small ocean or big estuary? Can Spec Publ Fish Aquat Sci 113:241-259

> Comeau LA, Campana SE, Chouinard GA (2002) Timing of Atlantic cod (Gadus morhua L.) seasonal migrations in the southern Gulf of St. Lawrence: interannual variability and proximate control. ICES J Mar Sci 59:333-351

> Cook RM, Cockrell BJ (1978) Predator ingestion rate and its bearing on feeding time and the theory of optimal diets. J Anim Ecol 47:529-547

Darbyson E, Benoît HP (2003) An atlas of the seasonal distribution of marine fish and invertebrates in the southern Gulf of St. Lawrence. Can Data Rep Fish Aquat Sci 1113. Fisheries and Oceans Canada, Ottawa
DFO (Fisheries and Oceans Canada) (2003) Proceedings of the zonal assessment meeting - Atlantic cod. DFO Can Sci Advis Sec Proc Ser 2003/021. Fisheries and Oceans Canada, Ottawa

DFO (Fisheries and Oceans Canada) (2009) Science advice on harvesting of northwest Atlantic harp seals (Pagophilus groenlandicus) in 2009. DFO Can Sci Advis Sec Sci Advis Rep 2008/058. Fisheries and Oceans Canada, Ottawa

Dutil JD, Lambert Y (2000) Natural mortality from poor condition in Atlantic cod (Gadus morhua). Can J Fish Aquat Sci 57:826-836

Frank KT, Brickman D (2000) Allee effects and compensatory population dynamics within a stock complex. Can J Fish Aquat Sci 57:513-517

> Fu C, Mohn R, Fanning LP (2001) Why the Atlantic cod (Gadus morhua) stock off eastern Nova Scotia has not recovered. Can J Fish Aquat Sci 58:1613-1623

Gende SM, Quinn TP, Willson MF (2001) Consumption choice by bears feeding on salmon. Oecologia 127:372-382

Gildberg A (2004) Digestive enzyme activities in starved pre-slaughter farmed and wild-captured, Atlantic cod (Gadus morhua). Aquaculture 238:343-353

Goulet AM, Hammil MO, Barette C (2001) Movements and diving of grey seal females (Halichoerus grypus) in the Gulf of St. Lawrence, Canada. Polar Biol 24:432-439

Grahl-Nielsen O, Haug T, Lindstrøm U, Nilssen KT (2011) Fatty acids in harp seal blubber do not necessarily reflect their diet. Mar Ecol Prog Ser 426:263-276

Grellier K, Hammond PS (2006) Robust digestion and passage rate estimates for hard parts of grey seal (Halichoerus grypus) prey. Can J Fish Aquat Sci 63:1982-1998

Gudmundson CJ, Zeppelin TK, Ream RR (2006) Application of two methods for determining diet of northern fur seals (Callorhinus ursinus). Fish Bull 104:445-455

Hammill MO (2005) Abundance of Northwest Atlantic grey seals in the Gulf of St. Lawrence and along the Nova Scotia Eastern Shore. Can Sci Advis Sec Res Doc 2005/036. Fisheries and Oceans Canada, Ottawa

- Hammill MO, Stenson GB (2000) Estimated prey consumption by harp seals (Phoca groenlandica), hooded seals (Cystophora cristata), grey seals (Halichoerus grypus) and harbour seals (Phoca vitulina) in Atlantic Canada. J Northwest Atl Fish Sci 26:1-23

> Hammill MO, Stenson GB, Myers RA, Stobo WT (1998) Pup production and population trends of the grey seal (Halichoerus grypus) in the Gulf of St. Lawrence. Can J Fish Aquat Sci 55:423-430

Hammill MO, Stenson GB, Proust F, Carter P, McKinnon D (2007) Feeding by grey seals in the Gulf of St. Lawrence and around Newfoundland. NAMMCO Sci Publ 6:135-152

> Harley SJ, Myers RA (2001) Hierarchical Bayesian models of length-specific catchability of research trawl surveys. Can J Fish Aquat Sci 58:1569-1584

Harvey V, Côté SD, Hammil MO (2008) The ecology of 3-D space use in a sexually dimorphic mammal. Ecography 31:371-380

Hauser DDW, Allen CS, Rich HBJ, Quinn TP (2008) Resident harbor seals (Phoca vitulina) in Iliamna Lake, Alaska: summer diet and partial consumption of adult sockeye salmon (Oncorhynchus nerka). Aquat Mamm 34:303-309

Hurlbut T, Clay D (1990) Protocols for research vessel cruises within the Gulf Region (demersal fish) (19701987). Can Ms Rep Fish Aquat Sci 2082. Fisheries and Oceans Canada, Ottawa

Hurlbut T, Morin R, Surette T, Swain DP, Benoît HP, LeBlanc C (2010) Preliminary results from the September 2009 
bottom-trawl survey of the southern Gulf of St. Lawrence. Can Sci Advis Sec Res Doc 2010/044. Fisheries and Oceans Canada, Ottawa

Hutchings JA (2005) Life history consequences of overexploitation to population recovery in Northwest Atlantic cod (Gadus morhua). Can J Fish Aquat Sci 62:824-832

> Hutchings JA, Baum JK (2005) Measuring marine fish biodiversity: temporal changes in abundance, life history and demography. Philos Trans R Soc B 360:315-338

Ingenbleek Y (2006) The nutritional relationship linking sulfur to nitrogen in living organisms. J Nutr 136(Suppl): 1641S-1651S

Innes S, Lavigne DM, Earle WM, Kovacs KM (1987) Feeding rates of seals and whales. J Anim Ecol 56:115-130

Iverson SJ (2009) Tracing aquatic food webs using fatty acids: from qualitative indicators to quantitative determination. In: Arts MT, Brett MT, Kainz MJ (eds) Lipids in aquatic ecosystems. Springer Science, New York, NY, p 281-307

> Iverson SJ, Field C, Bowen D, Blanchard W (2004) Quantitative fatty acid signature analysis: a new method of estimating predator diets. Ecol Monogr 74:211-235

$>$ Jonsen ID, Mills-Flemming J, Myers RA (2005) Robust statespace modeling of animal movement data. Ecology 86: 2874-2880

Kleiber M (1975) The fire of life: an introduction to animal energetics. Robert E. Krieger Publishing, New York, NY

Koen-Alonso M (2007) A process-oriented approach to the multispecies functional response. In: Rooney N, McCann KS, Noakes DLG (eds) From energetics to ecosystems: the dynamics and structure of ecological systems. Springer, Dordrecht, p 1-36

> Koen-Alonso M, Yodzis P (2005) Multispecies modelling of some components of the marine community of northern and central Patagonia, Argentina. Can J Fish Aquat Sci 62:1490-1512

Lavigne DM, Innes S, Worthy GAJ, Kovacs KM (1986) Metabolic rate-body size relations in marine mammals. J Theor Biol 122:123-124

Lavigueur L, Hammill MO (1993) Distribution and seasonal movements of grey seals, Halichoerus grypus, born in the Gulf of St. Lawrence and eastern Nova Scotia shore. Can Field Nat 107:329-340

Lawson JW, Magalhaes AM, Miller EH (1998) Important prey species of marine vertebrate predators in the northwest Atlantic: proximate composition and energy density. Mar Ecol Prog Ser 164:13-20

Lilly GR, Murphy EF (2004) Biology, fishery and status of the 2GH and 2J3KL (northern) cod stocks: information supporting an assessment of allowable harm under the Species at Risk Act for the COSEWIC-defined Newfoundland and Labrador population of Atlantic cod (Gadus morhua). Can Sci Advis Sec Res Doc 2004/102. Fisheries and Oceans Canada, Ottawa

Mackinson S, Blanchard JL, Pinnegar JK, Scott R (2003) Consequences of alternative functional response formulations in models exploring whale-fishery interactions. Mar Mamm Sci 19:661-681

> Macpherson E, Duarte CM (1991) Bathymetric trends in demersal fish size: is there a general relationship? Mar Ecol Prog Ser 71:103-112

Marshall GJ (1998) Crittercam: an animal borne imaging and data logging system. Mar Technol Soc J 32:11-17

Matthiopoulos J, Smout S, Winship AJ, Thompson D, Boyd IL, Harwood J (2008) Getting beneath the surface of marine mammal-fisheries competition. Mammal Rev 38: $167-188$
Mohn R, Bowen WD (1996) Grey seal predation on the eastern Scotian Shelf: modelling the impact on Atlantic cod. Can J Fish Aquat Sci 53:2722-2738

Moore PG (2003) Seals and fisheries in the Clyde Sea area (Scotland): traditional knowledge informs science. Fish Res 63:51-61

Murie DJ, Lavigne DM (1985) Digestion and retention of Atlantic herring otoliths in the stomachs of grey seals. In: Beddington JR, Beverton RJH, Lavigne DM (eds) Marine mammals and fisheries. George Allen and Unwin Publishing, London, p 292-299

Myers RA, Bowen KG, Barrowman NJ (1999) Maximum reproductive rate of fish at low population sizes. Can J Fish Aquat Sci 56:2404-2419

Nordstrom CA, Wilson LJ, Iverson SJ, Tollit DJ (2008) Evaluating quantitative fatty acid signature analysis (QFASA) using harbour seals Phoca vitulina richardsi in captive feeding studies. Mar Ecol Prog Ser 360:245-263

Olesiuk PF (1993) Annual prey consumption by harbor seals (Phoca vitulina) in the Strait of Georgia, British Columbia. Fish Bull 91:491-515

Overholtz WJ, Link JS (2007) Consumption impacts by marine mammals, fish, and seabirds on the Gulf of MaineGeorges Bank Atlantic herring (Clupea harengus) complex during the years 1977-2002. ICES J Mar Sci 64: 83-96

Penry DL (1993) Digestive constraints on diet selection. In: Hughes RN (ed) Diet selection. Blackwell, Cambridge, MA, p 32-55

Phillips EM, Harvey JT (2009) A captive feeding study with the Pacific harbor seal (Phoca vitulina richardii): implications for scat analysis. Mar Mamm Sci 25:373-391

Punt AE, Butterworth DS (1995) The effects of future consumption by the cape fur seal on catches and catch rates of the cape hakes. 4. Modelling the biological interaction between cape fur seals Arctocephalus pusillus pusillus and the cape hakes Merluccius capensis and M. paradoxus. S Afr J Mar Sci 16:255-285

> Rochet MJ (1998) Short-term effects of fishing on life history traits of fishes. ICES J Mar Sci 55:371-391

Roffe TJ, Mate BR (1984) Abundance and feeding habits of pinnipeds in the Rogue River, Oregon. J Wildl Manage 48:1262-1274

Ronald K, Keiver KM, Beamish FWH, Frank R (1984) Energy requirements for maintenance and faecal and urinary losses of the grey seal (Halichoerus grypus). Can J Zool 62:1101-1105

Saltelli A, Tarantola S, Campolongo F (2000) Sensitivity analysis as an ingredient of modeling. Stat Sci 15:377-395

Savenkoff C, Swain DP, Hanson JM, Castonguay M and others (2007) Effects of fishing and predation in a heavily exploited ecosystem: comparing periods before and after the collapse of groundfish in the southern Gulf of St. Lawrence (Canada). Ecol Modell 204:115-128

Savenkoff C, Morissette L, Castonguay M, Swain DP, Hammill MO, Chabot D, Hanson JM (2008) Interactions between marine mammals and fisheries: implications for cod recovery. In: Chen J, Guo C (eds) Ecosystem ecology research trends. Nova Science Publishers, New York, NY, p 107-151

Savoie L, Surette T (2010) Results from the August 2008 sentinel bottom trawl survey of the southern Gulf of St. Lawrence. DFO Can Sci Advis Sec Res Doc 2010/033. Fisheries and Oceans Canada, Ottawa

Schwalme K, Chouinard GA (1999) Seasonal dynamics in feeding, organ weights, and reproductive maturation of Atlantic cod (Gadus morhua) in the southern Gulf of St 
Lawrence. ICES J Mar Sci 56:303-319

Shelton PA, Sinclair AF, Chouinard GA, Mohn R, Duplisea DE (2006) Fishing under low productivity conditions is further delaying recovery of Northwest Atlantic cod (Gadus morhua). Can J Fish Aquat Sci 63:235-238

Sih A (1980) Optimal foraging: partial consumption of prey. Am Nat 116:281-290

Sinclair AF (2001) Natural mortality of cod (Gadus morhua) in the Southern Gulf of St. Lawrence. ICES J Mar Sci 58: $1-10$

Smout S, Lindstrøm U (2007) Multispecies functional response of the minke whale Balaenoptera acutorostrata based on small-scale foraging studies. Mar Ecol Prog Ser 341:277-291

Sparling CE, Fedak MA (2004) Metabolic rates of captive grey seals during voluntary diving. J Exp Biol 207: 1615-1624

Steimle FW Jr, Terranova RJ (1985) Energy equivalents of marine organisms from the continental shelf of the temperate northwest Atlantic. J Northwest Atl Fish Sci 6: $117-124$

Stobo WT, Beck B, Horne JK (1990) Seasonal movements of grey seals (Halichoerus grypus) in the Northwest Atlantic. In: Bowen WD (ed) Population biology of sealworm (Pseudoterranova decipiens) in relation to its intermediate and seal hosts. Can Bull Fish Aquat Sci 222: 199-213

Swain DP (1993) Age- and density-dependent bathymetric pattern of Atlantic cod (Gadus morhua) in the southern Gulf of St. Lawrence. Can J Fish Aquat Sci 50:1255-1264

Swain DP (2011) Life-history evolution and elevated natural mortality in a population of Atlantic cod (Gadus morhua). Evol Appl 4:18-29

Swain DP, Chouinard GA (2008) Predicted extirpation of the dominant demersal fish in a large marine ecosystem: Atlantic cod (Gadus morhua) in the southern Gulf of St. Lawrence. Can J Fish Aquat Sci 65:2315-2319

Swain DP, Sinclair AF (1994) Fish distribution and catchability: What is the appropriate measure of distribution? Can J Fish Aquat Sci 51:1046-1054

Swain DP, Sinclair A (2000) Pelagic fishes and the cod recruitment dilemma in the Northwest Atlantic. Can J Fish Aquat Sci 57:1321-1325

Swain DP, Sinclair AF, Chouinard GA, Drinkwater KF (2000) Ecosystem effects on pre-recruit survival of cod in the southern Gulf of St. Lawrence. DFO Can Sci Advis Sec Res Doc 2000/147. Fisheries and Oceans Canada, Ottawa

Swain, DP, Simon JE, Harris LE, Benoît HP (2006) Recovery potential assessment of $4 \mathrm{~T}$ and $4 \mathrm{VW}$ winter skate (Leu-

Editorial responsibility: Matthias Seaman,

Oldendorf/Luhe, Germany coraja ocellata): biology, current status and threats. Can Sci Advis Sec Res Doc 2006/003. Fisheries and Oceans Canada, Ottawa

Swain DP, Jonsen ID, Simon JE, Myers RA (2009a) A stagestructured state-space model to assess threats and management scenarios for data-deficient species-at-risk: estimating mortality trends in winter skate (Leucoraja ocellata, Family Rajidae). Ecol Appl 19:1347-1364

Swain, DP, Savoie L, Hurlbut T, Surette T, Daigle D (2009b) Assessment of the southern Gulf of St. Lawrence cod stock, February 2009. DFO Can Sci Advis Sec Res Doc 2009/037. Fisheries and Oceans Canada, Ottawa

Swain, DP, Benoît HP, Hammill MO, McClelland G, Aubrey É (2011) Alternative hypotheses for causes of the elevated natural mortality of southern Gulf cod: the weight of evidence. DFO Can Sci Adv Sec Res Doc 2011/036. Fisheries and Oceans Canada, Ottawa

Trzcinski MK, Mohn R, Bowen WD (2006) Continued decline of an Atlantic cod population: How important is gray seal predation? Ecol Appl 16:2276-2292

Tucker S, Bowen WD, Iverson SJ (2007) Dimensions of diet segregation in grey seals Halichoerus grypus revealed through stable isotopes of carbon $\left(\delta^{13} \mathrm{C}\right)$ and nitrogen $\left(\delta^{15} \mathrm{~N}\right)$. Mar Ecol Prog Ser 339:271-282

> Walters C, Kitchell JF (2001) Cultivation/depensation effects on juvenile survival and recruitment: implications for the theory of fishing. Can J Fish Aquat Sci 58:39-50

Williams TM, Estes JA, Doak DF, Springer AM (2004) Killer appetites: assessing the role of predators in ecological communities. Ecology 85:3373-3384

Wirsing AJ, Dill LM, Frid A (2008) Seascapes of fear: evaluating sublethal predator effects experienced and generated by marine mammals. Mar Mamm Sci 24:1-15

Worthy GAJ (1987a) Ecological energetics of harp and grey seals: implications from a simulation model. In: Huntley AC, Cost DP, Worthy GAJ, Castellini MA (eds) Marine mammal energetics. Allen Press, Lawrence, KS, p 227-246

Worthy GAJ (1987b) Metabolism and growth of young harp and grey seals. Can J Zool 65:1377-1382

Worthy GAJ (1990) Nutritional energetics in marine mammals: addendums. In: Dierauf LA (ed) CRC handbook of marine mammal medicine: health, disease and rehabilitation. CRC Press, Boca Raton, FL, p 489-520

> Yodzis P (1998) Local trophodynamics and the interaction of marine mammals and fisheries in the Benguela ecosystem. J Anim Ecol 67:635-658

Yodzis P (2001) Must top predators be culled for the sake of fisheries? Trends Ecol Evol 16:78-84

Submitted: January 19, 2011; Accepted: October 19, 2011

Proofs received from author(s): November 10, 2011 